\title{
Russian meat price transmission and policy interventions in 2014
}

\author{
Daria Loginova* (i) and Judith Irek@
}

\section{${ }^{*}$ Correspondence:}

daria.loginova@agroscope. admin.ch

Department

Socioeconomics, Research

Station Agroscope, Federal

Office of Economics, Tanikon

1,8356 Ettenhausen

Switzerland

\begin{abstract}
This article investigates price relationships in the Russian meat markets in 2011-2017. We use vector autoregression specifications to predict the transmission between consumer, producer, and import prices in the Russian pork, beef, and poultry markets. We consider the possible effects of substitution (between domestic product and import as well as between products in domestic markets), market protection in meat markets, short-term exchange rate policy, and trade price incentives. Our results suggest that meat producer prices responded to import prices, but not vice versa. Poultry and pork producers responded to all market protection measures-the ban of pork imports from the EU and the food embargo. Beef producer prices responded to the embargo. We also find that the single meat market segments may help predict price effects for substitutes. For instance, we find that the poultry consumer prices responded to consumer price changes in the beef and pork markets owing to assumed demand redistribution, but - in contrast to beef and pork - poultry consumer prices were not correlated with the lagged import and producer prices.
\end{abstract}

Keywords: Pork, Beef, Poultry, Trade ban, Substitution effect, Vector autoregression

\section{Introduction}

The protection policies in Russian agricultural markets and a Rouble crisis in 2014 (see the details in Rutland 2014; Wegren 2014) significantly changed the trade map around Russia in 2014 and onwards. They were followed by a sharp decline in import volumes, a domestic price growth, and an increase in agricultural production and exports during the post-embargo years in Russia (International Trade Centre 2020; Rosstat 2020). The price changes in Russian food markets were a considerable consequence of the policies of 2014 (Ponomareva and Magomedov 2017; Volchkova and Kuznetsova 2019; Cheptea and Gaigné, 2020).

Many previous studies investigated the food embargo in Russia in 2014 (Dillen 2015; Boulanger et al. 2016; Uzun and Loginova 2016; Gohin 2017; Kutlina-Dimitrova 2017; Banse et al. 2019; Fedoseeva and Herrmann 2019; Kadochnikov et al. 2019; Liefert et al. 2019; Volchkova and Kuznetsova 2019). Fewer studies aimed to investigate the other shocks of 2014 and quantify price effects in Russian food sectors (e.g. Kiselev et al. 2015; Götz and Jaghdani 2017; Cheptea and Gaigné 2020; Yugay et al. 2020). Previous studies agreed that after 2014, Russian food sectors destabilised in the short term, while Russian

(c) The Author(s) 2022. Open Access This article is licensed under a Creative Commons Attribution 4.0 International License, which permits use, sharing, adaptation, distribution and reproduction in any medium or format, as long as you give appropriate credit to the original author(s) and the source, provide a link to the Creative Commons licence, and indicate if changes were made. The images or other third party material in this article are included in the article's Creative Commons licence, unless indicated otherwise in a credit line to the material. If material is not included in the article's Creative Commons licence and your intended use is not permitted by statutory regulation or exceeds the permitted use, you will need to obtain permission directly from the copyright holder. To view a copy of this licence, visit http:// creativecommons.org/licenses/by/4.0/. 
food production permanently grew at the cost of consumer depletion and with the benefits of financial support from the government (Kiselev et al. 2015; Shagaida and Uzun 2016). Because a currency shock may also affect domestic food prices (Dreger et al. 2016; Wang et al. 2019; Yugay et al. 2020), one should consider this exchange rate effect as an indirect impact of trade disruptions.

In this article, we study how the economic interventions in 2014 contributed to price dependencies in the Russian meat markets. In particular, we analyse three exogenous interventions: (1) the pork ban, when Russia banned imports of live pigs, fresh pork, and other pig products from the EU; (2) the embargo, when the president of the Russian Federation introduced the food embargo as an 'anti-sanctions' measure; and (3) the exchange rate liberalisation of the Russian rouble. We hypothesise that these interventions affected domestic prices for producers, consumers, and trade owing to the loss of traditional and territorially close trade partners who previously had compensated the shortage or seasonality of domestic production in conditions of the stronger Russian currency. The hypothesis and the expectations about the results of the present study are in line with the previous observations on protectionist policies. ${ }^{1}$ The empirical strategy of the present study is to estimate the changes in prices in the medium term considering the effects of price transmission and the studied interventions.

We employ vector autoregression (VAR) models to study price transmission in a seven-year period. We have several reasons to focus our study on meat in Russia. Firstly, meat is among the main constituents in the diets of people in Russia, particularly if compared with vegetables and fruits (Shagaida and Uzun 2015b). Secondly, meat prices have less weather-driven seasonality and no seasonal production interruptions as is usually observed for crops. The absence of a clear weather pattern in the meat sector is a notable benefit in conditions of Russian agriculture and for the VAR specification. Thirdly, the meat prices are directly affected by bans, whereas eggs, root vegetables, and grains are only affected on the level of input prices, on which we do not focus. ${ }^{2}$ Fourthly, since 2020, the large-scale producers of pork and poultry have organised the expansion of exports to the world markets ${ }^{3}$; therefore, the effects of substitution, protection, and currency on domestic prices could continue to be relevant mechanisms in the future. Finally, there are different degrees of self-sufficiency in Russian beef, pork, and poultry markets (Shagaida and Uzun 2015a, b), while these markets substitute each other. The difference in self-sufficiency and possible substitution effects could result in a different price behaviour during and after the events of 2014. We expect the strongest price changes in the import-dependent beef sector and weaker effects in the pork and poultry sectors. ${ }^{4}$ Therefore, the novelty of our study is that we consider the effects of

\footnotetext{
${ }^{1}$ Given the past evidence from international studies, we expect the food trade restrictions and crisis to affect both domestic producers and consumers. For instance, the experience of protectionist policies in East Asia introduced during the 1960s and 1970s has shown that in the 1980s the consumers had to pay food prices two to three times higher than the price level in international markets of that time (Anderson 1983). Koester (1991) concludes that the producers of most countries benefitted from postponed or restricted market liberalisation.

${ }^{2}$ Kuzminov et al. (2018) pointed out that the prices of imported goods and equipment grew driven by the economic sanctions, the devaluation of the national currency, and the declining economic growth.

3 The information was announced on the sites of national unions of producers in the sectors of poultry and pork: NSP (2020) and NSSRF (2020).

${ }^{4}$ In September 2015, compared with September 2014, the smallest price change was observed for frozen poultry (1\%), fresh pork and poultry (4\%), and potatoes (5\%), whereas the prices of fish increased by $25 \%$ to $40 \%$ and those of vegetables by $10 \%$ to $35 \%$, except for garlic prices, which increased by $75 \%$ (Smirnov 2016 ).
} 
substitution, currency, and protection policies for different economic agents in the three meat sectors with different self-sufficiency.

We present some background information and a review of previous studies in "The policies driving the Russian meat sector" section. Our data and method are described in "Data and empirical approach" section. Our results are presented in "Results" section, and "Discussion and conclusion" section concludes the study.

\section{The policies driving the Russian meat sector}

The government support of large-scale agriculture from 2003 to 2005 drove a transformation in Russian pork, poultry, and grain sectors, whereas the beef and milk sectors were experiencing problems (Serova 2007; Borodin 2016; Shagaida et al. 2016). The investments in the previously large-scale beef sector were minimally successful so that family farms produced most beef (Rosstat 2020). Prikhodko and Davleyev (2014) observed a substitution tendency between beef and cheaper poultry in the diets and budgets without quantifying the effect of substitution.

At the end of January 2014, Russia closed its market to pig products from the EU (European Commission 2014). In August 2014, the president of the Russian Federation introduced the food embargo as an 'anti-sanctions' measure. The list of the products under embargo did not include the wheat, sunflower product, and sugar (sugar beet product) markets. In 2014, these sectors were powerful enough to compete on the world market ${ }^{5}$ and provide agricultural export growth from 2014 onwards. ${ }^{6}$ However, these restrictions protected Russian pork, beef, and poultry producers. In autumn 2014, the Russian rouble to US dollar exchange rate doubled.

The food import restrictions in 2014 may have had similar consequences as earlier trade restrictions (see for instance Abbott and Paarlberg 1986). While the EU could divert the share of trade with Russia to other markets, Russian markets were expected to experience considerable price growth in the first year because imports cannot be easily substituted and domestic production has problems to expand productions significantly within the timeframe of the ban' (Dillen 2015). However, as had been predicted by Semenova and Sundikova (2015), the embargo had a positive impact on domestic agricultural producers, including producer price growth, whereas the negative developments of domestic consumption were more strongly related to the depreciation of the Russian rouble rather than to import restrictions (Kiselev et al. 2015; Shagaida and Uzun 2016). ${ }^{7}$ Kiselev et al. $(2015,2016)$ employed a partial equilibrium model to conclude about an expected average import prices increase by $20-40 \%$, producer prices increase by $15 \%$, and consumer prices increase by more than $20 \%$ for pork and $7 \%$ for poultry. They also showed that the meat imports from the countries under embargo had met only a small part of Russian demand. ${ }^{8}$ Kadochnikov et al. (2019) estimated the Rotterdam model

\footnotetext{
${ }^{5}$ See more about the competitiveness of Russia in the world market in Uzun and Loginova (2017).

6 The share of cereals in the total Russian agricultural export value was at a minimum of $29 \%$ in 2013 and at a maximum of 42\% in 2018 (International Trade Centre 2020).

7 However, Kuzminov et al. (2018) linked the growth in the prices of imported goods with the economic sanctions and the devaluation of the national currency.

8 The Russian pork and poultry markets differ significantly from the beef market; thus, we assume that the effects for meat subcategories are too diverse to assess them in one group.
} 
for demand functions of imported and domestically produced commodities in Russia and concluded that a sharp increase in import costs was the main factor for changes in meat consumption, whereas the effects of income and substitution (of domestic production with imports) were second and third, respectively, by importance. After 2014, beef imports from the EU were substituted with frozen meat from Brazil (Schierhorn et al. 2016). The pork and poultry sectors were almost self-sufficient so that the changes in imports were minor.

Several models were employed to show how strongly Russian consumers were affected. Berendeeva and Ratnikova (2018) used QUAIDS and Working-Leser models with correction of the price vector to analyse the effects of the embargo on demand. They found that the demand patterns had already begun to return to pre-shock trajectories after the end of 2014. ${ }^{9}$ The latest gravity model of international trade was assessed by Cheptea and Gaigné (2020), who estimated losses in welfare in Russia to be in the range of $0.2 \%$ to $0.6 \%$ (18 EUR to 58 EUR) of the revenue of the average Russian consumer in 2013. This estimate aligns with the earlier findings of Volchkova and Kuznetsova (2019) and is slightly less than that of Ponomareva and Magomedov (2017), who estimated equilibrium models and studied only Russian markets. Volchkova and Kuznetsova (2019) also found that 'producers capture $84 \%$ of this amount, importers $3 \%$, while deadweight loss amounts to $13 \%$.

The exchange rate, being a crucial factor of international trade, especially in the tradedependent agricultural sectors, was affected both by the sanctions and by the oil price development. The rouble crisis in autumn 2014 resembled the rouble crisis in summer $1998^{10}$ : the oil prices decreased dramatically leading to a budget deficit, a further currency depreciation, and increases in food prices. ${ }^{11}$ During the Russian rouble crisis in 2014, the Russian rouble to US dollar exchange rate doubled. For comparison, in the Russian rouble crisis in 1998 , it increased even more, by the factor $3.5 .^{12}$ In contrast to 2014, in 1998 the domestic markets did not recover after the shift to a market economy and were open for foods from Europe and the USA. ${ }^{13,14}$ The international trade of Russia in the period 1994-1999 was close to zero, whereas after the crisis in 2014, Russia covered $0.2 \%$ and $2 \%$ of the world food (and meat) export and import volumes, respectively (see Uzun et al. 2018). The effect of the exchange rate on food prices during the crisis in

\footnotetext{
9 The dynamics of retail trade volumes show that domestic consumers recovered from a real income drop only in the third quartile of 2016 (Rosstat 2020).

10 See the discussion on the drivers of the crisis of 1998 in Åslund (1998).

11 See the agricultural price dynamics in Russia from January 1993 to December 1995 in Loy and Weaver (1998). The price increases are visible in the price volatility presented by Arnade and Osborne (2004). The volatility was above zero and had sharp peaks.

12 In 1998, the exchange rate jumped to 20 RUB per 1 USD; in 2014, it jumped to 30 RUB. The monthly Consumer Price Index was $134 \%$ in September 1998 and 108-111\% after the shock, whereas from August 2014 to March 2015, it stayed around 101-103\% each month. One Russian rouble in 1998 equivalents 11 RUB in 2014 and 15 RUB in 2020 (by Consumer Price Index).

13 To the best of our knowledge, few studies investigated food prices around the crisis of 1998. The monthly food price series studied by Loy and Weaver (1998) is interrupted right before the crisis happened. Arnade and Osborne (2004) studied the food prices around the crisis, but they did not include exchange rates and focused on price transmission between the world market and several Russian regions.

14 After the crisis of 1998, 'the agricultural sector showed early signs of a positive response' (Brooks and Gardner 2004 p. 583), whereas the crisis of 2014 was even beneficial for some large-scale producers, resulting in increasing market shares of large-scale producers, especially in the poultry and pork sectors (Shagaida 2019). Russian beef and pork prices during the Russian rouble crisis in 1998 were studied by Osborne and Liefert (2004), who found low price and exchange rate transmissions in Russian agriculture in the period 1994-1999 and concluded that Russia was not well integrated into the world meat market.
} 
2014 is even less studied than that during the crisis in 1998. The exceptions are the VAR analyses for grain market prices by Burakov (2016) and Yugay et al. (2020) and the study on import substitution policy in the Russian pork sector by Götz and Jaghdani (2017).

The studies on the Russian meat market published in the 1990s and 2000s investigated the process of liberalisation of the Russian economy in general and of the Russian agricultural sector in particular. The crisis and embargo of 2014 launched the reorientation of the Russian trade to the east and south and the reinforcement of protectionist policies in Russian agriculture. The meat production growth in Russia, the more attractive exchange rate for exporters, and the decrease in domestic consumption served as incentives for domestic producers to enter international markets (hereafter addressed as 'export incentives' in the present article). While the pork trade might have been restricted by the cultural and religious preferences of neighbouring countries, poultry exports were expected to contribute to Russia's national income.

\section{Data and empirical approach}

With this study, we aim to reveal the contributions of the events of 2014 on the prices for meat products. We studied meat prices in Russia in a seven-year period from 2011 to 2017. This way, we covered a three-year period before and a three-year period after the policy events in 2014. We used consumer prices (in Russian roubles) provided by Rosstat, producer prices (in Russian roubles) provided by the Food and Agriculture Organization of the United Nations, trade information (in US dollars) provided by the International Trade Centre, and the average weighted exchange rate provided by the Central Bank of the Russian Federation. We mapped the producer, consumer, and trade prices (per kilogram) to each week of each year, assuming that from a price perspective, we can compare cattle prices to beef prices and poultry prices to chicken prices. This assumption is plausible because the main poultry trade in Russia is represented by chicken and the main cattle trade is represented by beef (International Trade Centre 2020; Rosstat 2020). The descriptive statistics and data visualisation are presented in Appendices 1 and 2.

We used vertical price transmission analysis, namely the VAR models, to assess the price change interdependencies among importer, exporter, producer, and consumer prices of a given meat product. We switched accordingly from 'VAR in levels' to 'VAR in first differences' because we found most of our prices to be $I(1)$, i.e. stationary in first differences. The explanation of the specification is presented in more detail in Appendix 3 , and the technical information and time series properties of the data are presented in Appendix 4.

Formally, we let $C, P, I$, and $E$ denote the logarithms of consumer, producer, import, and export prices, respectively, for each product $k=\{$ beef, poultry, pork $\}$ over time $t$, with $l$ denoting the lag of own price differences and $j$ the lag of other variables. $\Delta$ is a first-difference operator. Thus, we study prices in the same way as Götz and Jaghdani (2017) did in their analysis of the Russian pork sector. The corresponding intercepts for these prices are $\mu_{k}^{C}, \mu_{k}^{P}$, and $\mu_{k}^{I}$, and the corresponding error terms are $\varepsilon_{k, t}^{C}, \varepsilon_{k, t}^{P}$, and $\varepsilon_{k, t}^{I}$. The exchange rate RUB/USD is denoted with $E R$. In Eq. 1, additionally, consumer prices of other products $(m \neq k)$ are included to account for substitution effects. $D$ is a time dummy for exogenous intervention $n=\{$ embargo, porkban, exchange rate liberalisation $\}$, being 0 
before, and 1 after the respective intervention. The formulas for the models we assessed are as follows:

$$
\begin{aligned}
\Delta C_{k, t}= & \mu_{k}^{C}+\sum_{l} \rho_{l k}^{C} \Delta C_{k, t-l}+\sum_{j} \theta_{j k}^{C} \Delta\left(I_{k, t-j} \times E R_{t-j}\right)+\sum_{j} \alpha_{j k}^{C} \Delta P_{k, t-j}+\sum_{j} \sum_{m} \beta_{j m}^{C} \Delta C_{m, t-j}+\varepsilon_{k, t}^{C} \\
\Delta P_{k, t}= & \mu_{k}^{P}+\sum_{l} \rho_{l k}^{P} \Delta P_{k, t-l}+\sum_{j} \theta_{j k}^{P} \Delta\left(I_{k, t-j} \times E R_{t-j}\right) \\
& +\sum_{j} \gamma_{j k}^{P} \Delta\left(E_{k, t-j} \times E R_{t-j}\right)+\sum_{j} \sum_{n} \varphi_{n, t-j}^{P} D_{t-j}+\varepsilon_{k, t}^{P} \\
\Delta I_{k, t}= & \mu_{k}^{I}+\sum_{l} \rho_{l k}^{I} \Delta I_{k, t-l}+\sum_{j} \theta_{j k}^{I} \Delta\left(P_{k, t-j} \times 1 / E R_{t-j}\right)+\sum_{j} \sum_{n} \varphi_{n, t-j}^{I} D_{t-j}+\varepsilon_{k, t}^{I}
\end{aligned}
$$

The parameters to be estimated are $\mu, \rho, \theta, \alpha, \beta, \gamma$, and $\varphi$. For all assessed VAR models, we chose the number of lags based on the Akaike information criterion. The variables which appear only on the right-hand side of the equation (exchange rate and intervention dummies) are considered weakly exogenous, i.e. they are determined outside our equation system. Such VAR models including exogenous variables are sometimes also called VARX (Pesaran 2015). This model specification (1) resembles a model used by Götz and Jaghdani (2017) but additionally considers two more meat sectors, interrelations between the studied three sectors, and the changes in prices after several interventions; (2) resembles the model by Esposti and Listorti (2013) that considers price transmission between three dimensions, but our models use levels of the supply chain instead of spatial dimension; (3) also makes the development of the studied prices more comparable across the different data sources because we mainly use first differences. Johansen co-integration test results for the prices and the impulse response functions (IRFs) for these models are presented in Appendices 5 and 6. In results section, we chose only the equation of interest and interpreted the coefficients and their significance ${ }^{15}$.

\section{Results}

\section{Consumer prices and the effect of substitution}

Table 1 shows the relations between producer, trade, and consumer price changes, discovered with the VAR model for data at a weekly frequency. Taking the adjusted $R$-squared as a measure, the explanatory power of these models lies between 63 and 79\%, hinting at strong interdependencies between the studied prices. However, our model for pork consumer prices does not pass the Portmanteau test on serial correlation in the residuals (see robustness check with 14 lags in Appendix 8).

\footnotetext{
${ }^{15}$ We expect interrelation of producer and export prices in our model. This interrelation is more transparent in the export-oriented Russian wheat sector. To check our hypothesis, we applied the model to producer and export prices in the Russian wheat sector in Appendix 7. For wheat, we found the following effect: each 1 RUB of export price growth led to a 0.33 RUB producer price increase. However, the wheat market in Russia is characterised by a heterogeneous degree of market integration (Svanidze and Götz 2019a, b) owing to large distances. Therefore, the effect of wheat export prices on producer prices cannot be generalised for the whole country. We expect that for meat sectors, the analysis on a country level is more robust because meat production is less dependent on weather and regional factors. Therefore, we let this effect be assessed in the present model for meat prices.
} 
The best predictors for each of the consumer price changes are the lagged values of the respective price change $\left(\rho_{l k}^{C}\right)$. Therefore, there is a strong positive autocorrelation in each of the price changes. The estimates of $\rho_{l k}^{C}$ for the first lag range from 0.34 (poultry) to 0.45 (beef) to 0.62 (pork), i.e. a $1 \%$ increase in last period's pork price variation will lead to a $0.62 \%$ increase in the following period's price variation. The interdependencies between the different prices are weaker. Producer prices in the beef and poultry sectors were not significant for predicting consumer prices, whereas the consumer price for pork slightly reacted to the pork producer price change of the previous two weeks $(+0.02)$. The import prices appear to have had a small but significant influence on the consumer prices in the beef and pork sectors $(+0.008$ to +0.01$)$, whereas consumer prices for poultry experienced minor effects from the pork sector $(+0.17)$. All consumer prices changed relative to the prices of the previous two weeks. In our data, producer prices had no variation within one month but varied from month to month. However, we found that if transmission happened, producer prices transmitted to consumer prices with a lag of only one to two weeks, whereas the import prices transmitted with a lag of three to four weeks.

Because we assessed the model in first differences, the signs do not mean an increase or decrease in price levels but an increase or decrease in price changes, i.e. by how much percentage does the dependent variable $y$ change when an independent variable $x$ changes by 1 percent. The beef sector collected all the assumed substitution effects. First, the beef consumer prices constantly experienced small and weakly significant changes after prices in the poultry sector had changed. However, price changes in the third previous week contributed positively $(+0.11)$, whereas price changes in the fourth previous week contributed negatively $(-0.1)$. Furthermore, the consumer prices of beef were weakly interdependent with pork consumer prices two weeks prior to the respective consumer price. Second, poultry price changes were positively related to the pork price changes from two weeks ago $(+0.17)$ and were not related to beef consumer prices. The quantified effects align with observations by Prikhodko and Davleyev (2014) and indicate that consumers tend to substitute beef with poultry. Third, the pork consumer price was interdependent with the beef consumer price observed three to four weeks earlier, but it was not related to poultry consumer price. Considering our assumptions on substitution effects, this finding suggests that the average consumer does not tend to consume pork instead of poultry.

Our estimations demonstrate the following interdependencies. First, pork consumer prices allow predicting beef and poultry consumer prices with a lag of two weeks. Second, beef prices allow predicting pork prices and poultry prices allow predicting beef prices with a lag of two to four weeks each. The Granger test expectedly showed Granger causality because the prices were interdependent.

\section{Supply and the effect of the export incentives}

We assessed the relations between producer and trade prices by using monthly data (Table 2). Overall, importers did not respond to market protection interventions. This is reflected both in the low explanatory power of the models (adjusted $R$-squared: 0.04 for beef, 0.06 for poultry) and in the lack of significance in the parameter estimates. 
Table 1 Results of the vector autoregression models for consumer prices at a weekly frequency

\begin{tabular}{|c|c|c|c|}
\hline \multirow[t]{2}{*}{ Estimated parameter } & \multicolumn{3}{|c|}{ Dependent variable } \\
\hline & $\Delta C_{\text {Beef }, t}$ & $\Delta C_{\text {Poultry, } t}$ & $\Delta C_{\text {Pork }, t}$ \\
\hline \multicolumn{4}{|l|}{$\mu_{k}^{C}$} \\
\hline - & $0.03(0.02)$ & $0.01(0.01)$ & $0.04(0.03)$ \\
\hline \multicolumn{4}{|l|}{$\rho_{l k}^{C}$} \\
\hline EV & $\Delta C_{\text {Beef }, t-1}$ & $\Delta C_{\text {Poultry, } t-1}$ & $\Delta C_{\text {Pork }, t-1}$ \\
\hline$I=1$ & $0.45(0.05)^{* * *}$ & $0.34(0.06)^{* * *}$ & $0.62(0.06)^{* * *}$ \\
\hline $1=2$ & $0.20(0.06)^{* *}$ & $0.27(0.06)^{* * *}$ & $0.20(0.07)^{* *}$ \\
\hline$I=3$ & $0.05(0.06)$ & $0.02(0.06)$ & $-0.16(0.07)^{*}$ \\
\hline$l=4$ & $0.11(0.05) *$ & $0.19(0.05)^{* * *}$ & $-0.02(0.05)$ \\
\hline \multicolumn{4}{|l|}{$\beta_{i m 1}^{C}$} \\
\hline EV & $\Delta C_{\text {Poultry,t-j }}$ & $\Delta C_{\text {Beef, } t-j}$ & $\Delta C_{\text {Beef }, t-j}$ \\
\hline$j=1$ & $-0.04(0.05)$ & $0.10(0.06)$ & $-0.01(0.08)$ \\
\hline$j=2$ & $-0.05(0.05)$ & $-0.10(0.06)$ & $0.07(0.08)$ \\
\hline$j=3$ & $0.11(0.05)^{*}$ & $-0.10(0.06)$ & $-0.22(0.08)^{* *}$ \\
\hline$j=4$ & $-0.1(0.05)^{*}$ & $-0.005(0.05)$ & $0.16(0.07) *$ \\
\hline \multicolumn{4}{|l|}{$\beta_{j m 2}^{C}$} \\
\hline EV & $\Delta C_{\text {Pork }, t-j}$ & $\Delta C_{\text {Pork }, t-j}$ & $\Delta C_{\text {Poultry,t-j }}$ \\
\hline$j=1$ & $0.01(0.04)$ & $0.02(0.04)$ & $-0.04(0.07)$ \\
\hline$j=2$ & $0.11(0.05) *$ & $0.17(0.05)^{* * *}$ & $0.03(0.07)$ \\
\hline$j=3$ & $-0.04(0.05)$ & $-0.04(0.05)$ & $0.04(0.07)$ \\
\hline$j=4$ & $-0.06(0.04)$ & $0.03(0.04)$ & $0.02(0.07)$ \\
\hline \multicolumn{4}{|l|}{$\alpha_{j k}^{C}$} \\
\hline EV & $\Delta P_{\text {Beef }, t-j}$ & $\Delta P_{\text {Poultry }, t-j}$ & $\Delta P_{\text {Pork }, t-j}$ \\
\hline$j=1$ & $0.01(0.01)$ & $-0.001(0.007)$ & $0.02(0.01)^{* * *}$ \\
\hline$j=2$ & $0.01(0.01)^{*}$ & $0.007(0.007)$ & $0.02(0.01)^{* * *}$ \\
\hline$j=3$ & $0.01(0.01)$ & $0.007(0.007)$ & $0.01(0.007)$ \\
\hline$j=4$ & $0.01(0.01)$ & $-0.012(0.007)$ & $0.01(0.007)$ \\
\hline \multicolumn{4}{|l|}{$\theta_{j k}^{C}$} \\
\hline EV & $\Delta\left(I_{\text {Beef }, t-j} \times E R_{t-j}\right)$ & $\Delta\left(I_{\text {Poultry }, t-j} \times E R_{t-j}\right)$ & $\Delta\left(I_{\text {Pork }, t-j} \times E R_{t-j}\right)$ \\
\hline$j=1$ & $0.004(0.004)$ & $-0.001(0.003)$ & $-0.005(0.004)$ \\
\hline$j=2$ & $0.0005(0.003)$ & $0.001(0.003)$ & $0.000(0.004)$ \\
\hline$j=3$ & $0.01(0.004)^{* *}$ & $0.004(0.002)$ & $0.01(0.004) *$ \\
\hline$j=4$ & $0.008(0.004)^{*}$ & $0.003(0.002)$ & $0.01(0.004)^{* *}$ \\
\hline Portmanteau test ( $p$ value) & 0.14 & 0.10 & 0 \\
\hline ARCH test ( $p$ value) & 1 & 1 & 1 \\
\hline Normality test ( $p$ value) & 0 & 0 & 0 \\
\hline Stability test & Passed & Passed & Passed \\
\hline Granger test ${ }^{\circ}$ & 0 & 0 & 0 \\
\hline Number of observations & 358 & 358 & 358 \\
\hline Adjusted $R$-squared & 0.64 & 0.79 & 0.67 \\
\hline
\end{tabular}

EV stands for explanatory variable. Significance codes: ${ }^{\prime * * * \prime} p \leq 0.001,{ }^{\prime * * *} p \leq 0.01,{ }^{\prime{ }^{\prime * \prime}} p \leq 0.05,{ }^{\prime \prime} p \leq 0.1$. Akaike information criterion is used to choose the number of lags in each model. Portmanteau test uses 40 lags, according to the default setting of Portmanteau test in Stata specification. ARCH test uses 24 lags. ${ }^{\circ} \mathrm{p}$ value for $\mathrm{H}_{0}$ : dependent variable does not Grangercause explanatory variable

However, the importers responded to producer prices. In the pork sector, this response was two months after the change in producer prices and was the strongest by magnitude and significance $(+0.46)$, whereas the poultry and beef importers reacted to producer prices faster (after one month) but weaker $(+0.28$ and +0.16 , respectively). Therefore, the change in the prices of importers was driven by the increased competition with domestic producers. 
Taking domestic producer prices as the dependent variable, we see no influence from import prices in any of the meat sectors. However, the different policy shocks appear to have had a significant effect on meat prices. After the pork ban, the average logarithmic difference of producer prices increased (pork: +0.04 ; poultry: +0.04 ; beef: no significance), whereas after the embargo we found the opposite tendency (pork: -0.082 ; poultry: -0.04 ; beef: -0.07 , two months later).

The export prices are insignificant in all the models for producers. In addition, the explanatory power of the model in the beef sector is low. Therefore, we conclude that there was no clear dependence between the producer and export prices on Russian meat markets in 2011-2017 and exporting meat during this period did not influence producer prices.

In the period from 2011 to 2017, the meat export expansion potential, especially into pork and poultry world markets, was only under study, and the meat producer organisations raised the question of meat export collaboration only in early 2019. Osborne and Liefert (2004) did not find a transmission of world prices and exchange rates to Russian meat markets because of the low trade volumes in the period 1994-1999. We assume that the effect of export incentives could show up only later, when the Russian meat export business developed and trade volumes increased.

\section{Summary and limitations}

Table 3 shows the summarised results and reports the sign of the estimated effect if it is significant and 'Not sign'. if it is insignificant.

We found that the meat import prices responded to the domestic producer prices. Currency liberalisation and trade bans did not change the import price behaviour for any of the meat products. Therefore, we conclude that the import prices of beef, poultry, and pork were affected by competition with domestic producers.

We found that producer prices changes of poultry and pork increased after the pork ban and decreased after the embargo. The beef producer prices did not respond to the pork ban but responded to the embargo. In the pork, poultry, and beef sectors, this effect transmitted to import prices. We also did not find any evidence that domestic meat producer prices responded to meat trade prices.

More complex price mechanisms seem to have been at work for consumer prices. We considered only the effects of import and producer prices, substituting markets, market protection measures, and exchange rate liberalisation. Although most market protection measures affected meat producers, consumer prices responded to these changes differently. In the beef and pork sectors, consumer prices responded to import and producer prices. Poultry consumer prices did not correlate with the import and producer prices of poultry. In addition, we found strong effects of substituting markets. Poultry consumer prices might change because of the shocks in the other sectors only, namely because of the shocks in the pork consumer prices, as our models show. Looking at interventions pass through consumer prices, we noticed that the pork ban indirectly affected pork consumer prices and led to changes of consumer prices in the markets of substitutes. 
Table 2 Results of the vector autoregression models for importers and producers

\begin{tabular}{|c|c|c|c|}
\hline \multirow[t]{2}{*}{ Estimated parameter, the explanatory variable } & \multicolumn{3}{|l|}{ Product $^{\circ \circ \circ}$} \\
\hline & $k=$ Beef & $k=$ Pork & $k=$ Poultry \\
\hline \multicolumn{4}{|l|}{ Dependent variable: $\Delta l_{t}$ in USD } \\
\hline$\mu_{k}^{\prime}$ & $0.002(0.005)$ & $0.003(0.01)$ & $0.001(0.01)$ \\
\hline$\rho_{l=1, k^{\prime}}^{\prime}$ lag of $\Delta l_{t}$ & $0.03(0.11)$ & $0.12(0.10)$ & $-0.13(0.11)$ \\
\hline$\rho_{l=2, k^{\prime}}^{\prime} \operatorname{lag}$ of $\Delta I_{t}$ & & $-0.05(0.10)$ & \\
\hline$\theta_{j=1, k^{\prime}}^{l} \Delta P_{\text {Product }, t-1} \times 1 / E R_{t-1}$ & $0.16(0.07)^{*}$ & $0.027(0.10)$ & $0.28(0.12) *$ \\
\hline$\theta_{j=2, k^{\prime}}^{\prime} \Delta P_{\text {Product }, t-2} \times 1 / E R_{t-2}$ & & $0.46(0.10)^{* * *}$ & \\
\hline$\varphi_{n=1, j=1}^{\prime}$, Embargo & $-0.001(0.02)$ & $-0.014(0.05)$ & $-0.04(0.04)$ \\
\hline$\varphi_{n=1, j=2^{\prime}}^{\prime}$ Embargo & & $-0.006(0.05)$ & \\
\hline$\varphi_{n=2, j=1}^{\prime}$, Pork ban & $0.012(0.01)$ & $0.07(0.05)$ & $0.04(0.03)$ \\
\hline$\varphi_{n=2, j=2}^{\prime}$ Pork ban & & $-0.05(0.05)$ & \\
\hline$\varphi_{n=3, j=1}^{\prime}$,Exchange rate liberalisation & $-0.017(0.02)$ & $-0.03(0.06)$ & $0.005(0.04)$ \\
\hline$\varphi_{n=3 j=2}^{\prime}$ Exchange rate liberalisation & & $0.03(0.05)$ & \\
\hline Portmanteau test ( $p$ value) & 1 & 0.76 & 1 \\
\hline ARCH test ( $p$ value) & 1 & 1 & 1 \\
\hline 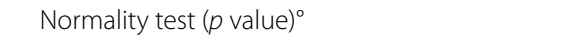 & 0 & 0 & 0 \\
\hline Stability test & passed & passed & passed \\
\hline Granger test ( $p$ value) $)^{\circ \circ}$ & 0.46 & 0.46 & 0 \\
\hline Number of observations & 84 & 84 & 84 \\
\hline Adjusted $R$-squared & 0.04 & 0.30 & 0.06 \\
\hline$p$ value for $F$-test (model significance) ${ }^{000}$ & 0.14 (no) & 0 (yes) & 0.07 (yes) \\
\hline \multicolumn{4}{|l|}{ Dependent variable: $\Delta P_{t}$ in $\mathrm{RUB}$} \\
\hline$\mu_{k}^{P}$ & $0.003(0.004)$ & $-0.001(0.005)$ & $-0.001(0.004)$ \\
\hline$\rho_{l=1, k^{\prime}}^{P} \Delta P_{t-1}$ & $-0.14(0.12)$ & $0.27(0.1)^{*}$ & $0.02(0.1)$ \\
\hline$\rho_{l=2, k^{\prime}}^{P} \Delta P_{t-2}$ & $0.04(0.12)$ & & \\
\hline$\theta_{j=1, k^{\prime}}^{P} \Delta /_{\text {Product }, t-1} \times E R_{t-1}$ & $-0.001(0.06)$ & $0.07(0.05)$ & $0.05(0.04)$ \\
\hline$\theta_{j=2, k^{\prime}}^{P} \Delta /_{\text {Product }, t-2} \times E R_{t-2}$ & $0.01(0.05)$ & & \\
\hline$\gamma_{j=1, k^{\prime}}^{P} \Delta E_{\text {Product }, t-1} \times E R_{t-1}$ & $0.012(0.02)$ & $0.007(0.008)$ & $0.007(0.02)$ \\
\hline$\gamma_{j=2, k^{\prime}}^{P} \Delta E_{\text {Product }, t-2} \times E R_{t-2}$ & $0.002(0.02)$ & & \\
\hline$\varphi_{n=1, j=1}^{P}$ Embargo & 0.05 (0.03) & $-0.082(0.02)^{* * *}$ & $-0.04(0.02) *$ \\
\hline$\varphi_{n=1, j=2}^{P}$, Embargo & $-0.07(0.03) *$ & & \\
\hline$\varphi_{n=2, j=1}^{P}$, Pork Ban & $0.003(0.03)$ & $0.04(0.01)^{* *}$ & $0.04(0.01) * * *$ \\
\hline$\varphi_{n=2, j=2}^{P}$, Pork Ban & $0.002(0.03)$ & & \\
\hline$\varphi_{n=3, j=1}^{P}$, Exchange rate liberalisation & $0.06(0.03)$ & $0.037(0.02)$ & $-0.006(0.01)$ \\
\hline$\varphi_{n=3, j=2}^{P}$, Exchange rate liberalisation & $-0.05(0.03)$ & & \\
\hline Portmanteau test ( $p$ value) & 1 & 0.73 & 1 \\
\hline ARCH test ( $p$ value) & 1 & 1 & 1 \\
\hline 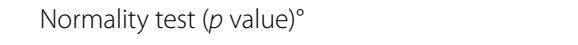 & 0 & 0 & 0 \\
\hline Stability test & passed & passed & passed \\
\hline Granger test ( $p$ value $)^{\circ \circ}$ & 0.03 & 0.26 & 0.43 \\
\hline Observations (number) & 84 & 84 & 84 \\
\hline Adjusted $R$-squared & 0 & 0.26 & 0.12 \\
\hline$p$ value for $F$-test (model significance) $)^{000}$ & 0.55 (no) & 0 (yes) & 0.01 (yes) \\
\hline
\end{tabular}

Significance codes: ${ }^{* * * \prime} p \leq 0.001,{ }^{* * * \prime} p \leq 0.01,{ }^{\prime * \prime} p \leq 0.05,{ }^{\prime \prime} p \leq 0.1$. Akaike information criterion is used to define the number of lags. Portmanteau test uses 40 lags, according to default setting of Portmanteau test in Stata specification. ARCH test uses 24 lags. ${ }^{\circ}$ The rejected normality is considered not problematic if more than 40 observations are employed (see Ghasemi and Zahediasl 2012). ${ }^{\circ} \mathrm{H}_{0}$ : dependent variable does not Granger-cause explanatory variable. ${ }^{\circ \circ}$ Overall significance in regression analysis; $H_{0}$ : The fit of the intercept-only model and the assessed model are equal 
Several assumptions have to be considered when interpreting the results of our models. We assume that (1) the transmission of the effects happens in a way we specify in "Data and empirical approach" section and Appendix 3; (2) the consumer prices are the prices of market equilibrium; (3) the suppliers of poultry, pork, and beef do not coordinate the between-sector prices and outputs, so that the supply in one market does not affect the supply in the other markets; (4) the demand can switch from one market to another. Given (2), (3), and (4), the development of prices beyond the sector supply and demand effects are driven by demand redistribution from the sectors producing the foods substitutes. Assumptions (2), (3), and (4) are defined to include and assess substitution effects in our models. We did not consider the effect of consumer prices on producer prices in our models. Instead, we assume that consumers are price-takers and cannot influence the producer price setting, but they can redistribute their demand. In our models, the supply in one market does not affect the supply in other markets, whereas the demand does.

\section{Discussion and conclusion}

This study reveals several patterns in price behaviour in Russian meat markets. In poultry and pork markets, we found upward and downward shifts in producer price changes after the pork ban and the embargo, respectively. The beef producer prices only responded to the embargo (downward shift in producer price changes). The results of our models indicate that the consumer prices in one meat market may be helpful to predict the consumer prices in the substituting meat market, because the prices may interdepend. Although we did not find an effect of export incentives in the Russian meat sectors in the period 2011-2017, we demonstrated this effect in the Russian wheat sector and concluded that an export incentive effect can appear in better-developed export businesses. We also show that suppliers' prices may sometimes be unable to predict consumer prices, as the Russian poultry market demonstrates. However, in Russian pork and beef markets, both the import prices and the domestic producer prices changes were useful to predict consumer prices changes. The effect of exchange rate liberalisation on food prices was not significant in the medium term.

Our study contributes to the existing analysis of the meat sector and meat consumers in Russian markets in several ways. As shown in "The policies driving the Russian meat sector" section, several previous studies estimated the effects of the embargo, the pork ban, and exchange rates, albeit often in other agricultural sectors and with less focus on price interdependencies and substitution effects in Russian meat markets. The equilibrium models of Kiselev et al. (2016) were able to forecast price changes in different sectors but did not distinguish the effects of Russian rouble devaluation, the pork ban, and substitution effects in meat markets. Our study compares these interventions and shows their importance for price dependencies for meat markets. Cheptea and Gaigné (2020), Volchkova and Kuznetsova (2019), Ponomareva and 


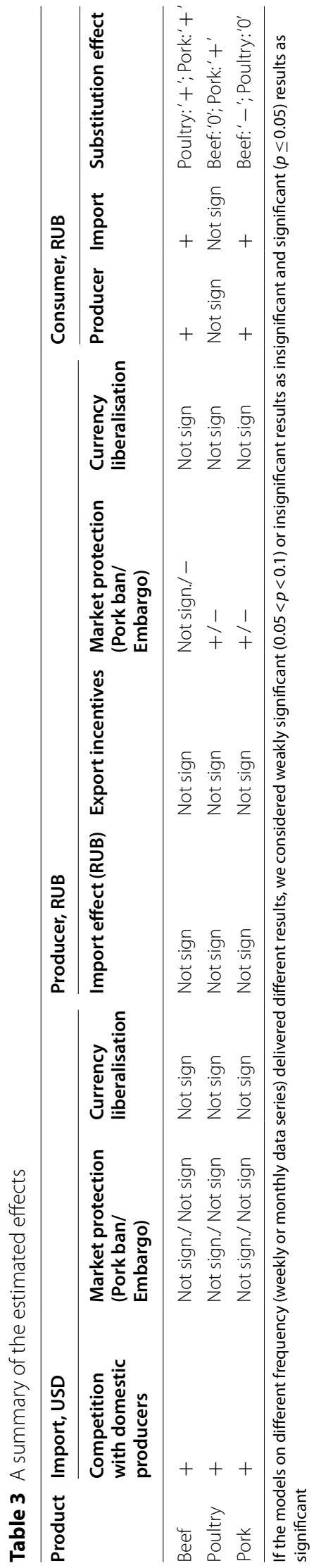


Magomedov (2017), and Boulanger et al. (2016) studied import restrictions and welfare effects by using trade prices and assuming the transmission of the effects from importers to consumers, which our models show was not always the case in Russian meat markets. Although the share of imports from banned countries was high in total import volumes, the share of imports in consumption was lower and substitutable by reorienting trade and increasing domestic production. Finally, the most related study in terms of specification and markets by Götz and Jaghdani (2017) thoroughly examined Russian pork prices but did not consider the substitution effects with other meat products as discussed by Prikhodko and Davleyev (2014). Therefore, we contribute to price transmission studies by considering the effects of substitution, currency, and sectoral self-sufficiency for different economic agents in the meat sectors in Russia in 2014. Like most of the previous studies on this subject, our results support the hypothesis that the interventions affected domestic prices for Russian suppliers and consumers. However, the mentioned methodological differences between the studies, as well as the design and limitations of the present study, do not allow a direct comparison of the results.

We expected to find direct effects of the 2014 policy interventions on meat prices, especially in import-dependent sectors. However, what our empirical models showed more clearly, are strong interrelationships between the prices in different meat segments. Our results demonstrate that it is important to analyse the consequences of trade bans also for prices in the sectors that are highly self-sufficient, because these sectors can overtake the demand when less self-sufficient sectors suffer from ban-related price effects. This can partially explain why beef prices did not react to the pork ban, whereas pork and poultry prices did.

The expansion of production and the protective measures in Russia did not lead to a reduction of domestic consumer and producer prices in local currency. After Russian rouble depreciation, most prices in US dollars decreased but increased in Russian roubles. The effects we found suggest that even food prices that were not affected directly by interventions could still be affected indirectly by the prices of foods substitutes. Overall, the interventions launched a chain of distributional, societal, and political consequences, which were unfavourable for Russian consumers but beneficial for Russian producers. The setting and the results of our study justify the consideration of the effects of competition, market protection, currency liberalisation, export incentives, and substitution effects in future models on prices along the supply chain in Russian and other markets. 


\section{Appendix 1: Descriptive statistics of the studied prices}

\begin{tabular}{|c|c|c|c|c|c|c|c|c|c|c|}
\hline \multirow[t]{2}{*}{ Price } & \multirow[t]{2}{*}{ Statistic } & \multicolumn{3}{|l|}{ Beef } & \multicolumn{3}{|c|}{ Poultry } & \multicolumn{3}{|l|}{ Pork } \\
\hline & & 2013 & 2014 & 2015 & 2013 & 2014 & 2015 & 2013 & 2014 & 2015 \\
\hline \multirow[t]{4}{*}{ Consumer (weekly, RUB) } & Mean & 246.4 & 255.2 & 308.2 & 109.7 & 120.2 & 135.9 & 213.3 & 246.7 & 277.0 \\
\hline & Variation & 1.2 & 69.5 & 57.2 & 7.1 & 147.5 & 5.1 & 6.8 & 509.1 & 5.4 \\
\hline & Minimum & 244.9 & 244.2 & 282.7 & 107.0 & 106.3 & 133.4 & 210.3 & 213.8 & 271.1 \\
\hline & Maximum & 248.6 & 277.4 & 315.4 & 116.3 & 137.4 & 140.2 & 219.8 & 274.9 & 280.2 \\
\hline \multirow[t]{4}{*}{ Producer (monthly, RUB) } & Mean & 72.0 & 74.6 & 93.8 & 54.5 & 64.2 & 71.3 & 71.7 & 94.3 & 103.0 \\
\hline & Variation & 3.8 & 11.7 & 10.0 & 3.2 & 54.5 & 4.8 & 17.3 & 169.2 & 34.5 \\
\hline & Minimum & 69.6 & 70.3 & 84.7 & 51.9 & 53.3 & 68.3 & 64.7 & 71.7 & 92.3 \\
\hline & Maximum & 75.0 & 81.6 & 97.1 & 59.1 & 73.4 & 75.0 & 77.5 & 108.4 & 109.1 \\
\hline \multirow[t]{4}{*}{ Export (monthly, USD) } & Mean & 6.4 & 5.9 & 4.4 & 1.2 & 1.1 & 1.1 & 3.9 & 4.1 & 2.1 \\
\hline & Variation & 0.5 & 0.4 & 0.1 & 0.0 & 0.0 & 0.0 & 0.8 & 1.6 & 0.5 \\
\hline & Minimum & 5.4 & 4.6 & 3.7 & 1.1 & 0.9 & 0.9 & 2.3 & 2.3 & 0.4 \\
\hline & Maximum & 7.3 & 7.0 & 5.1 & 1.4 & 1.2 & 1.2 & 5.3 & 6.8 & 3.0 \\
\hline \multirow[t]{4}{*}{ Import (monthly, USD) } & Mean & 4.3 & 4.2 & 3.5 & 1.6 & 1.8 & 1.4 & 3.4 & 4.0 & 3.1 \\
\hline & Variation & 0.0 & 0.0 & 0.0 & 0.0 & 0.1 & 0.0 & 0.0 & 0.2 & 0.0 \\
\hline & Minimum & 4.1 & 4.0 & 3.1 & 1.5 & 1.5 & 1.3 & 3.3 & 3.3 & 2.5 \\
\hline & Maximum & 4.4 & 4.4 & 3.7 & 1.7 & 2.4 & 1.8 & 3.5 & 4.7 & 3.5 \\
\hline \multirow[t]{4}{*}{ Currency (weekly, RUB for 1 USD) } & Mean & 31.89 & 38.88 & 61.29 & & & & & & \\
\hline & Variation & 1.03 & 44.88 & 38.78 & & & & & & \\
\hline & Minimum & 30.04 & 33.31 & 49.58 & & & & & & \\
\hline & Maximum & 33.38 & 61.51 & 72.28 & & & & & & \\
\hline
\end{tabular}

The table reports descriptive statistics partially. The variation of weekly and monthly prices is not comparable.The data on the exchange rate and consumer prices were available at a weekly frequency, whereas producer, import, and export prices were available only monthly. Hence, we implicitly assumed that there was no variation at a higher frequency. ${ }^{16}$ Even without an econometric analysis, one can see the higher level of producer and consumer prices for all analysed meat products after 2014 as compared with their levels before 2014. The price variation after the events of 2014 was lower than in 2013 for all beef prices, for poultry consumer prices, and for pork export prices. The average exchange rate (RUB/ USD) in Russia doubled in 2015 compared with 2013. The exchange rate is important in our study because the shocks of the exchange rate can transmit to trade prices. Although the variation of import prices in US dollars stayed low, the import price, when imports entered Russian markets, was converted to the price in Russian roubles and captured the exchange rate shocks. The exchange rate might be affected by sanctions and oil-gas prices. Moreover, the effects of these events might lag or spread over time, depending on the situation of federal reserves and the decisions of the Central Bank of the Russian Federation.

\footnotetext{
${ }^{16}$ We are aware that this model assumption does not hold, as agricultural markets operate on a weekly, if not daily frequency. Using such lower-frequency data can lead to an overestimation of the price adjustment parameters (Amikuzuno 2011). Consequently, the size of the parameter estimates from the weekly and monthly models is not directly comparable. However, the direction, relative size, and statistical significance of the parameters do give us a good indication of the price adjustment effects.
} 


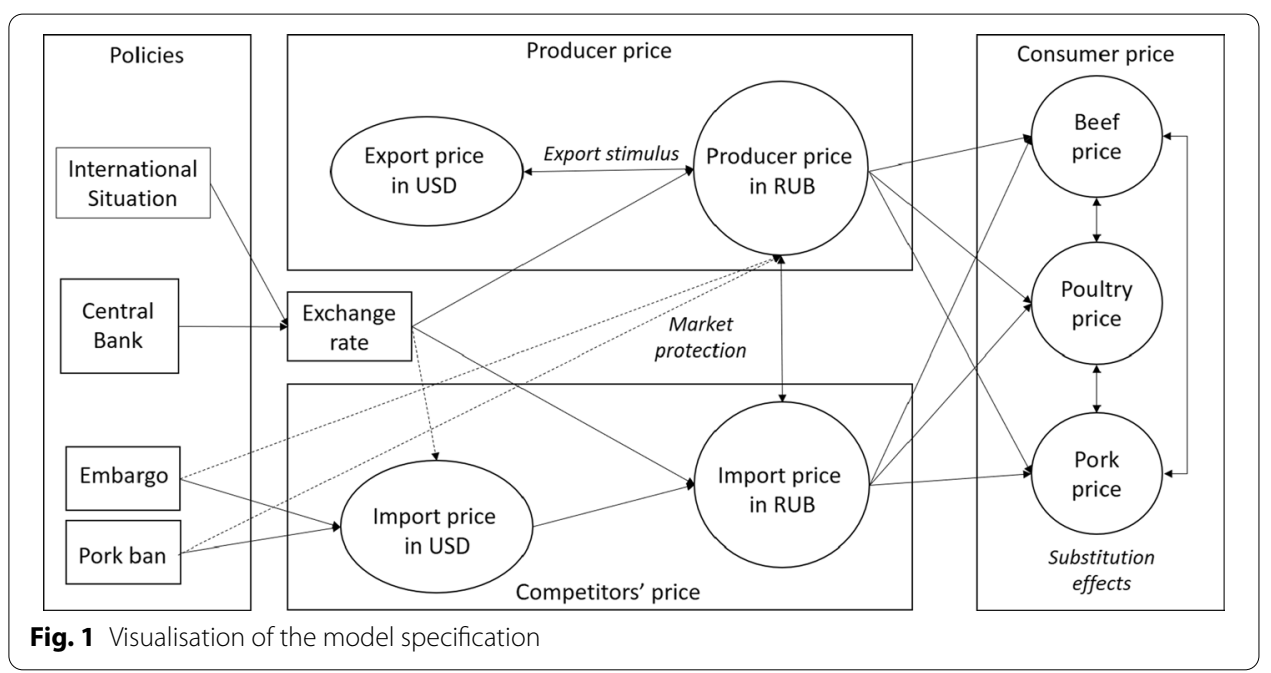

\section{Appendix 2: Data presentation}

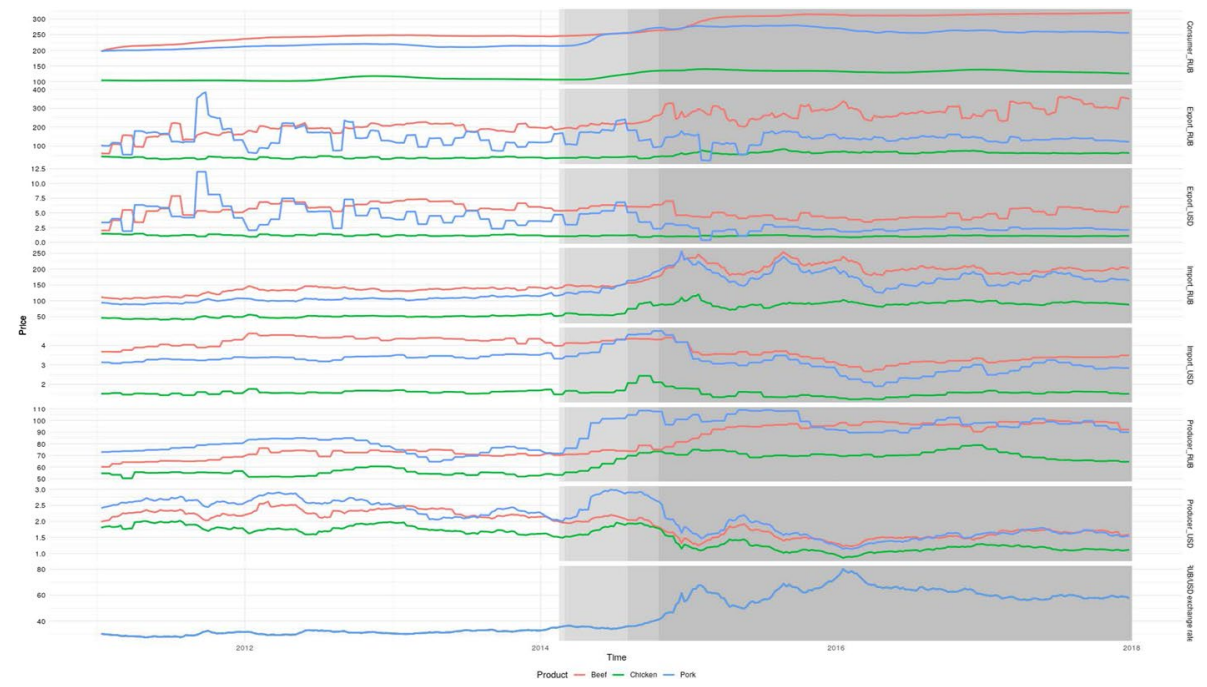

\section{Appendix 3: Discussion on the specification}

The possible transmission of shocks, introduced by interventions, and macroeffects can violate prices. Figure 1 depicts the price relations we assumed and visualises the model specification we performed. Because all events were unexpected by economic agents, we can assume that the effect of any event on prices did not occur before the event happened.

As shown in Fig. 1, we assumed that the trade ban interventions we studied restricted food imports and affected import prices and producer prices. The sanctions were introduced in March and later contributed to an exchange rate shock in September, because the sanctions were expanded to the Russian bank sector in the period of the global oil price decrease (Rutland 2014). However, the sanctions could already have affected trade decisions of market 
participants in March and thus could indirectly have affected import prices. The resulting prices that affected the consumer price were the producer price in Russian roubles and the import price in US dollars multiplied by the exchange rate. All these components experienced the policy and market effects in 2014 and therefore led to the changes in consumer prices.

The consumers purchased food of domestic and foreign origin and were price-takers. Following a rational choice theory, and neglecting a potential home bias and product preferences, they can be assumed to have selected the product with the lower price given the same quality. We linked the products (beef, poultry, and pork) in Fig. 1 to illustrate price effects of substitution of the products in consumers' diets. To consider the dependence of each consumer price on other consumer prices in the models, we simply included the consumer prices of the substituting product in the model for the consumer price of the studied product (see Cummings et al. 1994, who performed a similar approach for programme substitution). Beyond statistics, we know that the consumer prices are the prices of equilibrium when the supply meets the demand. If suppliers of poultry, pork, and beef do not coordinate the prices and outputs, we can assume that the supply in one market was not affected by changes in the supply of other markets ${ }^{17}$. In addition, we assumed that demand has a different nature and can switch from one market to another in a week, whereas producers have to put effort into increasing production volumes or adopting new prices. If the development of prices beyond the sector supply effects is driven by demand redistribution from another sector, we can estimate the substitution effect on prices. Under these assumptions, we have an explanation for a significant result, but we still cannot exclude coincidental correlation.

Although the sanctions and currency developments did not target the food sector, the depreciation of the Russian rouble made domestic producers more competitive in the world markets and decreased the competitiveness of foreign goods. Isaac and Rapach (1997), assessing the effect of monetary policy on the farming sector, concluded that monetary shocks do not affect relative farm prices. Nonetheless, we tested this indirect effect on producer prices in our model. We assumed that the export price in US dollars multiplied by a higher exchange rate made foreign markets much more attractive than stagnating domestic markets. We could show this effect of attractiveness and competitiveness of the world market by linking export prices and producer prices, even though the trade flow has the opposite direction. Producers also experienced much weaker price and quantity competition in domestic markets after trade bans and Russian rouble depreciation. These circumstances could allow producers to increase prices in Russian roubles in the domestic markets and for export, although the higher export price in Russian roubles subsequently became lower in US dollars after the Russian rouble depreciation.

We did not consider the effect of meat substitution with non-meat products or with products produced by producers other than the agricultural organisations (peasant farms and households). The producer prices in Russian statistics exist only for agricultural organisations (and we used these prices), whereas peasant farms and

\footnotetext{
${ }^{17}$ Russia's biggest pork and beef company, Miratorg, produced almost 10\% of Russian pork and beef in 2019, so that the weak violation of this assumption is possible for these $10 \%$ of production if the company has a joint policy in the beef and pork markets.
} 
households have a simplified form of reports ${ }^{18}$. The share of agricultural organisations in the domestic volume of production increased in the period 2011-2017 from 89 to $92 \%$ in the poultry sector, from 55 to $82 \%$ in the pork sector, and from only $30 \%$ to $33 \%$ in the cattle sector ${ }^{19}$. The increase in production in agricultural organisations was stronger than a simple replacement of the production of stagnating households. We could not consider the market share of agricultural organisations in our model because we would have needed information about the prices charged by domestic competitors (peasant farms and households), but we argue that the agricultural organisations could be considered as representatives of the Russian meat sectors at least for the segment of production that is traded in domestic and foreign markets. We also did not include the meat substitution with non-meat products because this would have dramatically decreased the degrees of freedom in our model, and the range of non-meat products that can potentially replace meat in Russian diets should have been more evident.

\section{Appendix 4: Technical information}

We used vector autoregression (VAR) models to study price interdependencies between different value chain stages, i.e. between producer, consumer, and trade prices of a given meat product (R-package 'vars' by Pfaff 2008a). In addition, we checked for unit roots using the Augmented Dickey-Fuller test (Dickey and Fuller 1979; Trapletti and Hornik 2019), tested for Granger causality with the Engle-Granger test (Granger 1969; Engle and Granger 1987; Pfaff 2008a), and checked for co-integration of the series with the Johansen test (Johansen 1991; Pfaff 2008b). The Augmented DickeyFuller test on stationarity around trend and intercept break rejected the unit root for many price levels; however, no unit roots were found in the prices in first differences (Table 4). Several of the analysed prices were non-stationary because most of them had a trend. The results of the tests do not allow us to study the series with 'VAR in levels'; therefore, we switched from 'VAR in levels' to 'VAR in first differences' for further analysis.

The results of Johansen tests are presented in Appendix 5. Additionally, we specified vector error correction models (VECMs) if the Johansen co-integration test revealed a co-integrating relationship between the variables (see Appendix 5). This allows us to identify how different prices are related in the long term, and if and how strongly prices react to changes in another price. However, because our main focus is on price changes as direct and indirect effects of the food ban, and on the interdependencies of price volatilities between different prices, we only report the Johansen test results and some key estimates of the VECMs, including the long-term co-integrating vector beta, and the error correction term alpha (see Appendix 5).

This approach allowed us to study weekly price volatilities defined as price changes as compared with prices in the previous week. Although the application of 'first difference' cleans price levels and possible policy effects, the results still allowed us to study how

\footnotetext{
${ }^{18}$ Peasant farms and households report incomes but not revenues from agricultural production, so that the prices cannot be calculated.

19 In the period $2011-2017,63-56 \%$ of cattle was produced in households, usually for home consumption (FedStat 2020).
} 
Table 4 Stationarity tests for the studied time series

\begin{tabular}{|c|c|c|c|c|c|c|}
\hline \multirow[t]{4}{*}{ Product } & \multirow[t]{4}{*}{ Variable (in logarithm) } & \multirow[t]{4}{*}{ Currency } & \multicolumn{4}{|c|}{ Augmented Dickey-Fuller test } \\
\hline & & & \multicolumn{2}{|c|}{ Weekly data } & \multicolumn{2}{|c|}{ Monthly data } \\
\hline & & & Levels & First difference & Levels & First difference \\
\hline & & & $H_{0}: /(0)$ & $H_{0}: /(1)^{\circ}$ & $H_{0}: /(0)$ & $H_{0}: /(1)^{\circ}$ \\
\hline Currency & Exchange rate & RUB/USD & -2.21 & $-5.46^{* * *}$ & -1.21 & $-3.59 * *$ \\
\hline \multirow[t]{8}{*}{ Beef } & Producer & RUB & -1.34 & $-7.32^{* * *}$ & -1.99 & $-3.34^{*}$ \\
\hline & & USD & $-3.14^{*}$ & $-6.13^{* * *}$ & -1.93 & $-5.2^{* * *}$ \\
\hline & Consumer & $R \cup B$ & -1.80 & $-4.46^{* * *}$ & -2.35 & -2.65 \\
\hline & & USD & - & - & - & - \\
\hline & Import & $R \cup B$ & -2.87 & $-6.16^{* * *}$ & -1.71 & $-4.58^{* * *}$ \\
\hline & & USD & -2.51 & $-5.83^{* * *}$ & -2.18 & $-3.95^{* *}$ \\
\hline & Export & RUB & $-6.09 * * *$ & $-9.54 * * *$ & $-3.93^{* *}$ & $-4.78^{* * *}$ \\
\hline & & USD & $-4.26 * * *$ & $-9.05^{* * *}$ & -2.31 & $-4.34^{* * *}$ \\
\hline \multirow[t]{8}{*}{ Pork } & Producer & $R \cup B$ & -2.34 & $-5.39 * * *$ & -2.48 & $-4.26^{* * *}$ \\
\hline & & USD & $-3.37^{* *}$ & $-5.34^{* * *}$ & -2.63 & $-4.73^{* * *}$ \\
\hline & Consumer & $R \cup B$ & -1.45 & $-4.70 * * *$ & -2.09 & $-3.38 *$ \\
\hline & & USD & - & - & - & - \\
\hline & Import & $R \cup B$ & -2.69 & $-5.96 * * *$ & -1.87 & $-4.98 * * *$ \\
\hline & & USD & -2.65 & $-5.28 * * *$ & -2.44 & $-4.85^{* * *}$ \\
\hline & Export & $R \cup B$ & $-5.67 * * *$ & $-8.87^{* * *}$ & $-4.00 * *$ & $-5.81^{* * *}$ \\
\hline & & USD & $-4.79 * * *$ & $-8.68^{* * *}$ & $-3.18^{*}$ & $-5.34^{* * *}$ \\
\hline \multirow[t]{8}{*}{ Poultry } & Producer & $R \cup B$ & -1.57 & $-5.55^{* * *}$ & -2.42 & $-3.72 * *$ \\
\hline & & USD & $-3.37^{*}$ & $-5.35^{* * *}$ & -2.63 & $-4.73^{* * *}$ \\
\hline & Consumer & $R \cup B$ & -2.66 & $-3.46^{* *}$ & -1.88 & $-4.08^{* * *}$ \\
\hline & & USD & - & - & - & - \\
\hline & Import & $R \cup B$ & -2.62 & $-6.34^{* * *}$ & -2.51 & $-4.14^{* * *}$ \\
\hline & & USD & -2.98 & $-6.00^{* * *}$ & -2.89 & $-4.08^{* * *}$ \\
\hline & Export & RUB & -3.04 & $-7.25^{* * *}$ & -2.18 & $-6.17^{* * *}$ \\
\hline & & USD & $-4.87^{* * *}$ & $-8.28^{* * *}$ & $-4.55^{* * *}$ & $-5.65^{* * *}$ \\
\hline
\end{tabular}

- Monthly producer and trade prices are stationary according to an Augmented Dickey-Fuller test without trend, only intercept, except for the beef producer price ( $p$ value $=0.12$ ). No significant trend found for first differences

Stationarity decision based on $5 \%$ significance level. Significance codes: ${ }^{\prime * * *^{\prime}} p \leq 0.01,{ }^{\prime * *^{\prime}} p \leq 0.05,{ }^{\prime * \prime} p \leq 0.1$

price changes are transmitted among different prices, either along the value chain (e.g. between importer and consumer prices) or among potentially substituting products (e.g. pork and chicken). 


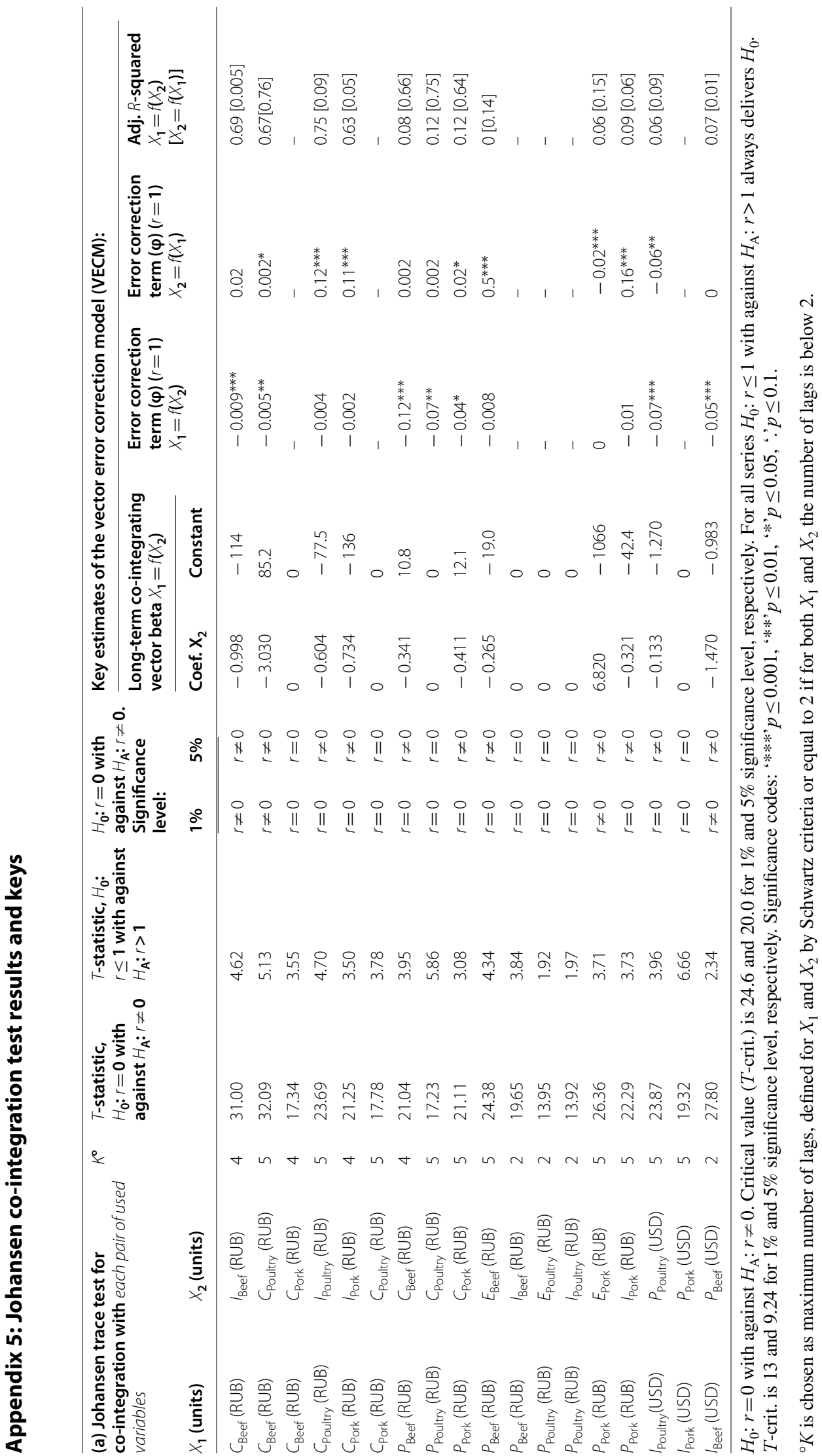




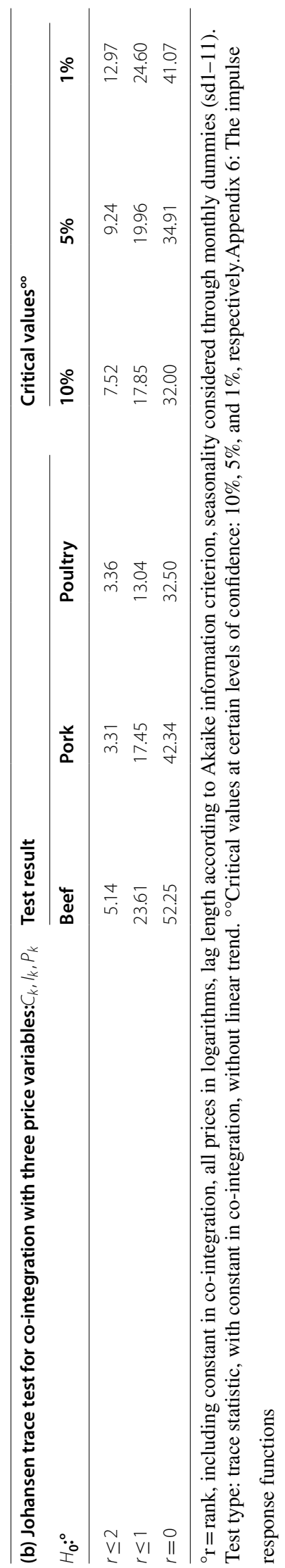


(1) for consumer prices volatilities

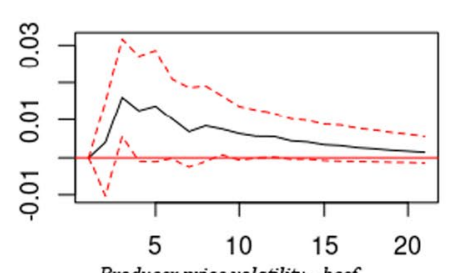

a) Beef
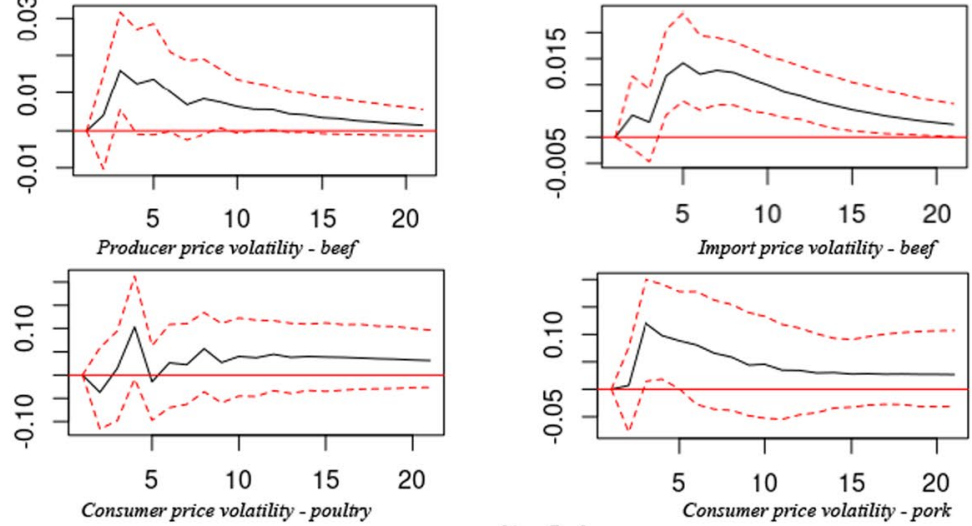

b) Pork
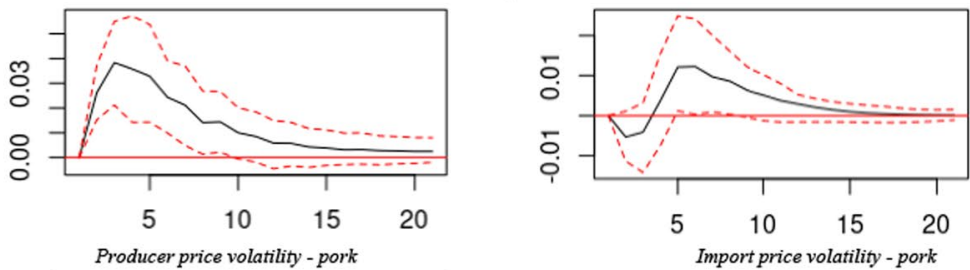

Producer price volatility - pork
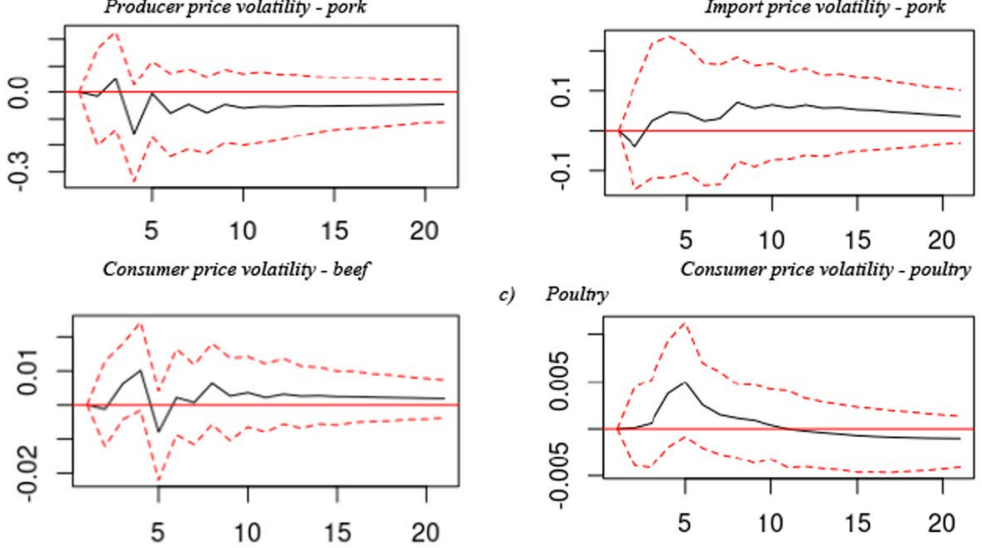

c) Poulny
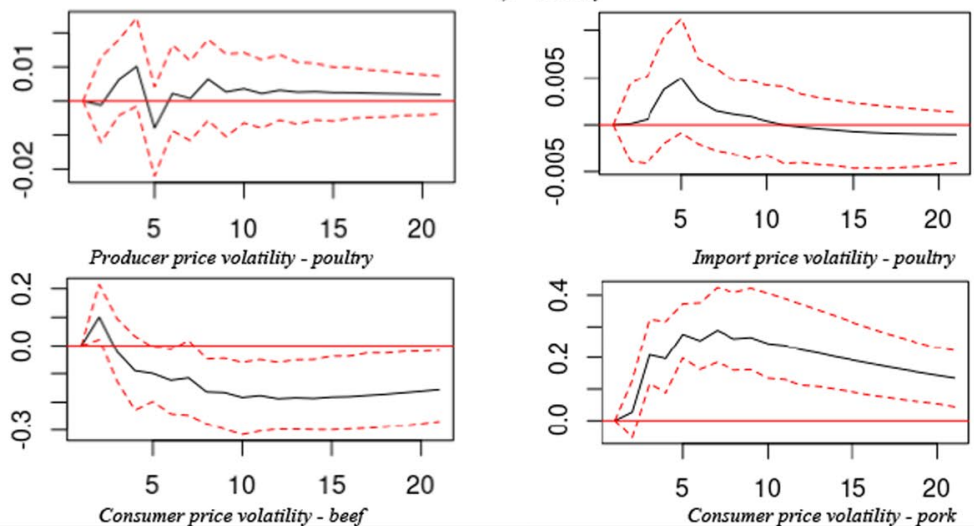

Notes: The prices are in first differences. The $\mathrm{y}$-axis shows the price response, the $\mathrm{x}$-axis shows the periods in weeks. The impulse response functions are non-cumulative. The plotted confidence intervals are $95 \%$, the errors bands are bootstrapped (200 runs). Models include 4 lags. 
(2) for producer price volatilities
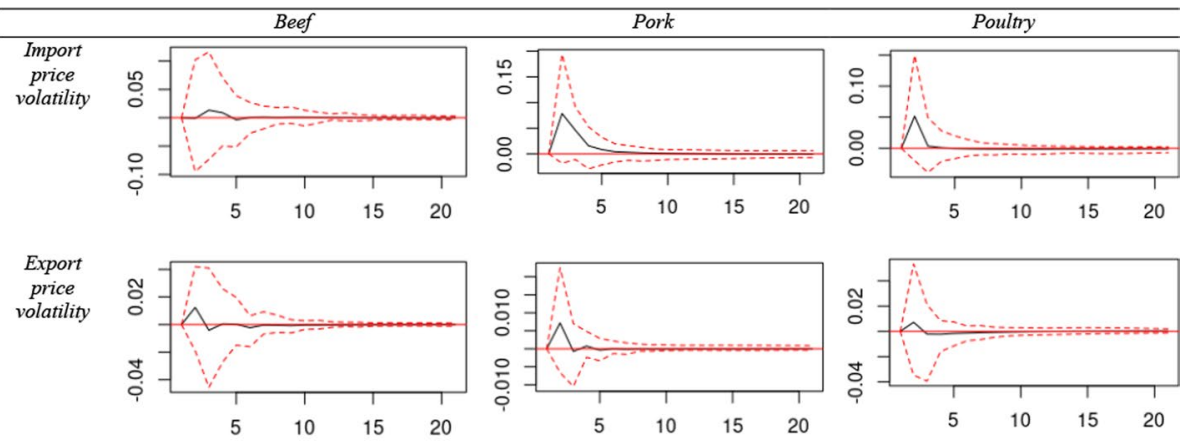

Notes: The prices are in first differences. The $\mathrm{y}$-axis shows the price response, the $\mathrm{x}$-axis shows the periods in months. The impulse response functions are non-cumulative. The plotted confidence intervals are $95 \%$, the errors bands are bootstrapped (200 runs).

(3) for import prices

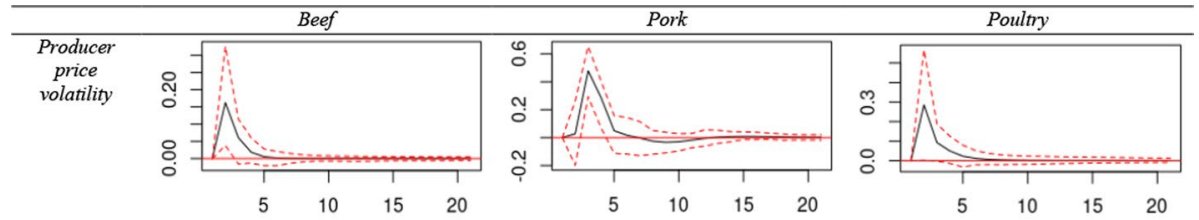

Notes: The prices are in first differences. The $\mathrm{y}$-axis shows the price response, the $\mathrm{x}$-axis shows the periods in months. The impulse response functions are non-cumulative. The plotted confidence intervals are $95 \%$, the errors bands are bootstrapped (200 runs)

(4) for policy shocks on meat prices

Figure 2 shows the impulse response functions (IRFs), illustrating how different prices (in first differences) reacted to a shock in the three exogenous variables (a) embargo, (b) pork ban, and (c) exchange rate liberalisation in the months after the respective shock. The IRFs show that the embargo had no significant effect on beef price changes, but had a significant negative effect on pork and poultry producer price changes. However, this effect was transitory and dissipated after three months for pork and after five months for poultry. Moreover, there was a lagged temporary response of the poultry import price change to the embargo, with a slight but 


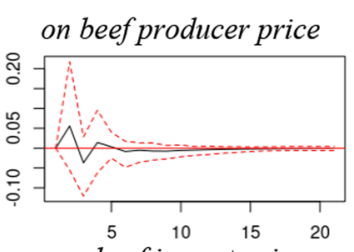

a) The effect of the shock 'embargo'

on pork producer price

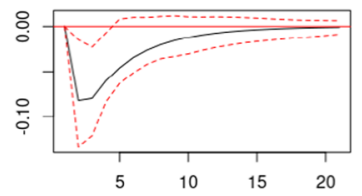

on pork import price

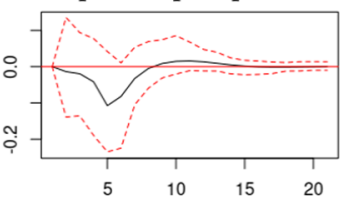

on poultry producer price

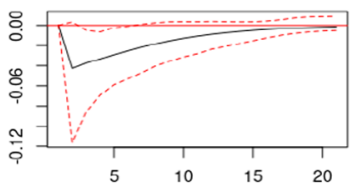

on poultry import price

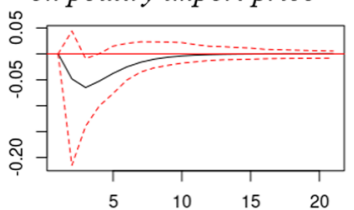

b) The effect of the shock 'pork ban'

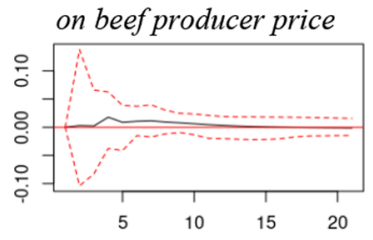
on pork producer price

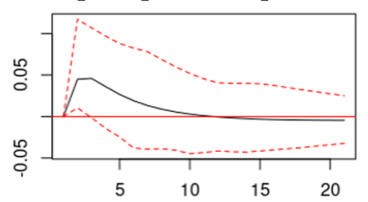

on poultry producer price

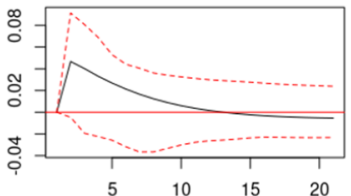

on pork import price
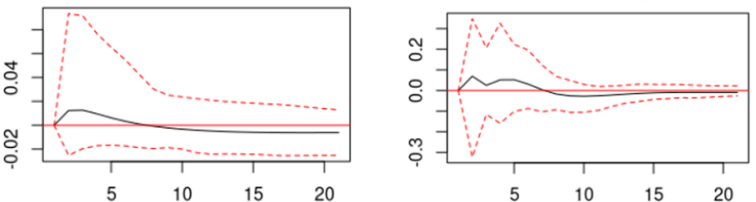

on poultry import price

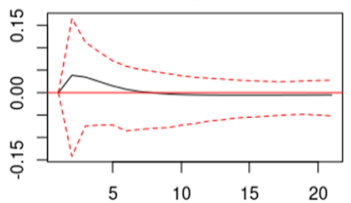

c) The effect of the shock 'exchange rate liberalisation'

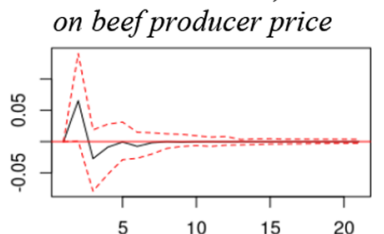
on pork producer price

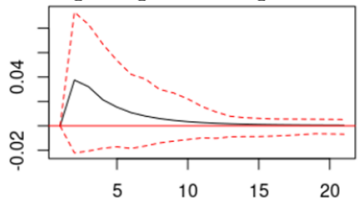

on poultry producer price

on beef import price

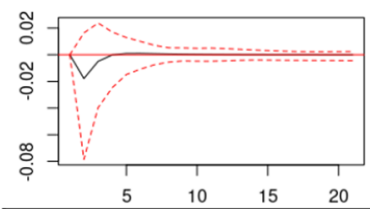

on pork import price
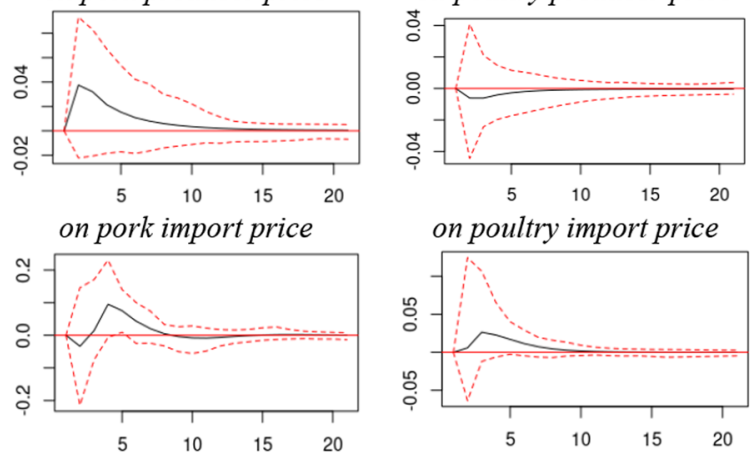

on poultry import price

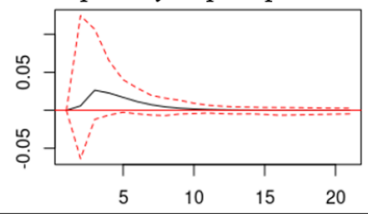

Notes: The prices are in first differences. The y-axis shows the price response, the x-axis shows the periods in months. The impulse response functions are non-cumulative. The plotted confidence intervals are $95 \%$, the error bands are bootstrapped (200 runs).

Fig. 2 Impulse response functions for policy shocks on meat prices

significant price decline after three months. Both the pork ban and the exchange rate liberalisation had no statistically significant effect on any of the analysed meat prices, as the $95 \%$ confidence intervals include zero in all the IRF plots. We have no embargo, pork ban, and exchange rate liberalisation dummies in the models for consumers, because we assume the potential vertical transmission of these effects from the producer and import prices to consumer prices. Therefore, we use the summary section to clarify the transmission of the effects across the meat prices. 


\section{Appendix 7: The model on producer, import, and export prices for Russian wheat to quantify the export incentives effect}

\begin{tabular}{ll}
\hline Explanatory variable & $\begin{array}{l}\text { Wheat } \\
\text { Producer }\end{array}$ \\
& Price (RUB) \\
& Monthly \\
\hline$\mu_{k^{\prime}}^{P}$ constant & $0.003(0.04)$ \\
$\rho_{l=1, k^{\prime}}^{P} \Delta P_{t-1}$ & $0.167(0.12)$. \\
$\gamma_{j=1, k^{\prime}}^{P} \Delta E_{\text {Product, }, t-1} \times E R_{t-1}$ & $-0.001(0.006)$ \\
$\gamma_{j=1, k^{\prime}}^{P} \Delta E_{\text {Product, },-1} \times E R_{t-1}$ & $0.338(0.06)^{* * *}$ \\
Portmanteau test $(p$ value) & 0.02 \\
ARCH test $(p$ value) & 0.57 \\
Normality test ( $p$ value $)^{\circ}$ & 0 \\
Stability test & passed \\
Granger test & \\
Number of observations & 0.6 \\
Adjusted $R$-squared & 84 \\
Stationary series & 0.29 \\
Model significance & all \\
\hline
\end{tabular}

${ }^{\circ}$ The rejected normality is considered not problematic if more than 40 observations are employed (see Ghasemi and Zahediasl 2012).

${ }^{\circ} \mathrm{H}_{0}$ : Wheat Producer Price does not Granger-cause explanatory variable.

Significance codes: ‘***’ $\leq 0.001$, ‘**’ $\mathrm{p} \leq 0.01$, ‘*’p $\leq 0.05$, ‘’p $\leq 0.1$. Akaike information criteria from four lags choose lags $=4$; however, in the model with four lags, only the coefficient $\left(0.35^{* * *}\right)$ of the first lag of Export Price is significant.

\section{Appendix 8: Dealing with autocorrelation in residuals in the model for pork consumer prices}

The model for pork consumer prices presented in Table 1 suffers from autocorrelation in residuals, and, therefore, the estimated model parameters may be biased. We included as many lags in the equation as needed until this issue was eliminated in the model (see Table 5 and Fig. 3). The minimal number of lags to provide the plausibility of the model by the Portmanteau test is 14 . The additional lags, however, do not majorly affect the conclusions we derive from the model in Table 1. 
Table 5 The model for pork consumer prices with 14 lags

\begin{tabular}{|c|c|c|c|c|c|}
\hline \multicolumn{3}{|c|}{ Effects of substitution (consumer prices in other meat markets) } & \multicolumn{3}{|c|}{ Pork chain effects (prices in pork markets) } \\
\hline Product & Lag & Estimation (SE) & Level & Lag & Estimation (SE) \\
\hline & no & $0(0)$ & & & \\
\hline \multirow[t]{14}{*}{ Beef } & 1 & $-0.05(0.09)$ & Consumer & 1 & $0.62(0.07)^{* * *}$ \\
\hline & 2 & $0.11(0.10)$ & & 2 & $0.22(0.08)^{* *}$ \\
\hline & 3 & $-0.19(0.10)$ & & 3 & $-0.24(0.08)^{* *}$ \\
\hline & 4 & $0.14(0.10)$ & & 4 & $0.07(0.08)$ \\
\hline & 5 & $0(0.10)$ & & 5 & $-0.09(0.08)$ \\
\hline & 6 & $-0.26(0.10)^{* *}$ & & 6 & $-0.04(0.08)$ \\
\hline & 7 & $0.23(0.10) *$ & & 7 & $0.05(0.08)$ \\
\hline & 8 & $0.05(0.10)$ & & 8 & $0.04(0.08)$ \\
\hline & 9 & $-0.01(0.10)$ & & 9 & $0.02(0.08)$ \\
\hline & 10 & $0.16(0.10)$ & & 10 & $-0.08(0.08)$ \\
\hline & 11 & $-0.13(0.10)$ & & 11 & $-0.04(0.08)$ \\
\hline & 12 & $-0.07(0.09)$ & & 12 & $-0.07(0.08)$ \\
\hline & 13 & $0.10(0.09)$ & & 13 & $0.16(0.08)$ * \\
\hline & 14 & $-0.10(0.07)$ & & 14 & $0.05(0.06)$ \\
\hline \multirow[t]{28}{*}{ Poultry } & 1 & $0.04(0.08)$ & Importer & 1 & $0(0)$ \\
\hline & 2 & $0.06(0.09)$ & & 2 & $0(0)$ \\
\hline & 3 & $-0.02(0.09)$ & & 3 & $0.01(0) *$ \\
\hline & 4 & $0(0.09)$ & & 4 & $0.02(0) * * *$ \\
\hline & 5 & $0.04(0.09)$ & & 5 & $0(0)$ \\
\hline & 6 & $-0.17(0.09)$ & & 6 & $-0.01(0)$ \\
\hline & 7 & $0.10(0.09)$ & & 7 & $0(0)$ \\
\hline & 8 & $-0.04(0.09)$ & & 8 & $-0.01(0)$ \\
\hline & 9 & $-0.08(0.09)$ & & 9 & $0(0)$ \\
\hline & 10 & $0.04(0.09)$ & & 10 & $0.01(0)$ \\
\hline & 11 & $-0.11(0.09)$ & & 11 & $0.01(0)$ \\
\hline & 12 & $0.16(0.09)$ & & 12 & $0(0)$ \\
\hline & 13 & $0.03(0.08)$ & & 13 & $-0.01(0)^{*}$ \\
\hline & 14 & $-0.03(0.08)$ & & 14 & $0(0)$ \\
\hline & & & Producer & 1 & $0.02(0.01)^{* *}$ \\
\hline & & & & 2 & $0.03(0.01)^{* * *}$ \\
\hline & & & & 3 & $0.01(0.01)$ \\
\hline & & & & 4 & $0.01(0.01)$ \\
\hline & & & & 5 & $0.01(0.01)$ \\
\hline & & & & 6 & $0(0.01)$ \\
\hline & & & & 7 & $0(0.01)$ \\
\hline & & & & 8 & $-0.01(0.01)$ \\
\hline & & & & 9 & $0.02(0.01)$ \\
\hline & & & & 10 & $0.01(0.01)$ \\
\hline & & & & 11 & $0.01(0.01)$ \\
\hline & & & & 12 & $0.01(0.01)$ \\
\hline & & & & 13 & $-0.02(0.01)$ \\
\hline & & & & 14 & $-0.01(0.01)$ \\
\hline Portmanteau test ( $p$ value) & & 0.06 & & & \\
\hline ARCH test ( $p$ value) & & 1 & & & \\
\hline Normality test ( $p$ value) & & 0 & & & \\
\hline Stability test & & passed & & & \\
\hline Granger test & & 0 & & & \\
\hline Number of observations & & 328 & & & \\
\hline Adjusted $R$-squared & & 0.70 & & & \\
\hline
\end{tabular}

See also Fig. 3 for the impulse response functions for this model

Significance codes: ${ }^{\prime * * * \prime} p \leq 0.001,{ }^{\prime * * \prime} p \leq 0.01,{ }^{* * \prime} p \leq 0.05$, , $p \leq 0.1$. ARCH test uses 24 lags. Portmanteau test uses 40 lags 


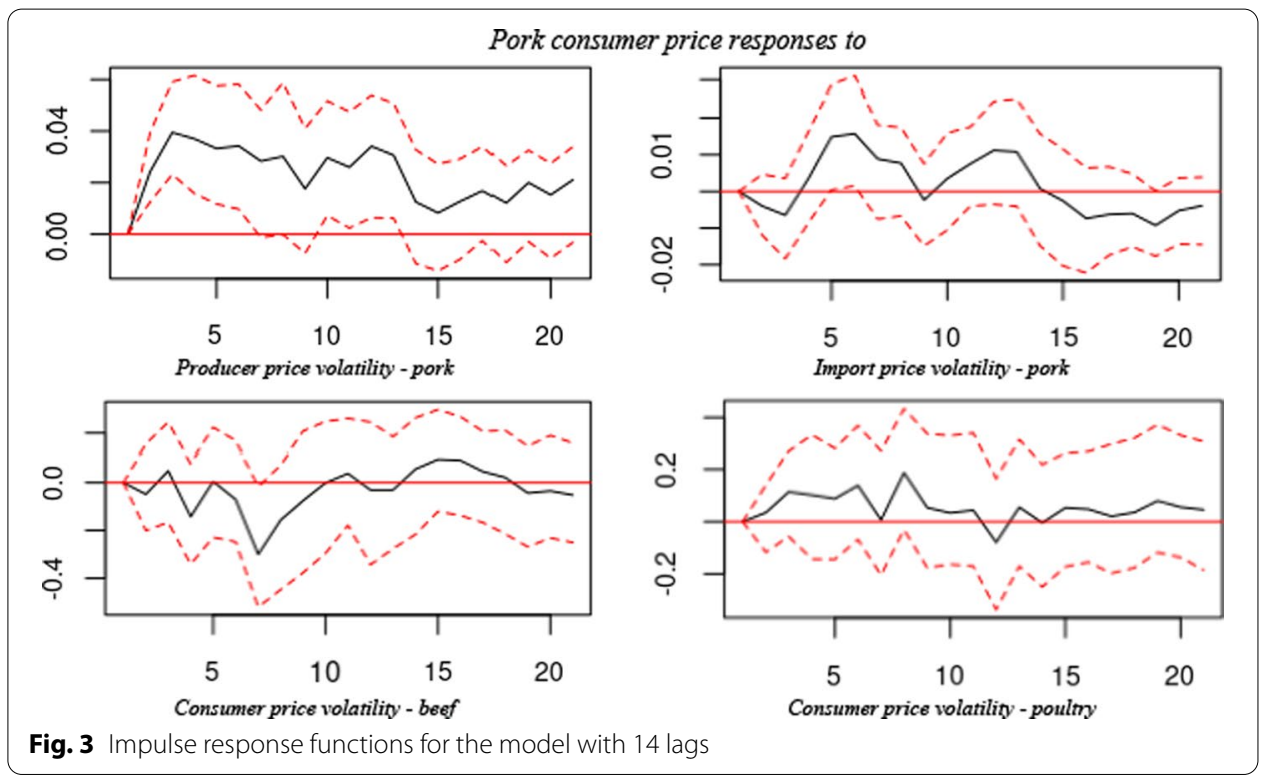

\section{Abbreviations}

ARCH: The autoregressive conditional heteroskedasticity; EU: European Union; IRF: The impulse response function; NSP: Russian Union of Poultry Producers, Moscow, Russia; NSSRF: Russian Union of Pork Producers, Moscow, Russia; QUAIDS: A Quadratic Almost Ideal Demand System; Rosstat: Russian Statistics, Moscow, Russia; RUB: The Russian rouble; USD: The dollar of the United States of America; US(A): The United States of America; VAR: Vector autoregression; VARX:Vector autoregression models including exogenous variables; VECM: Vector error correction model.

\section{Acknowledgements}

We thank the anonymous reviewers for providing helpful comments on earlier drafts of the manuscript. In particular, one reviewer dedicated considerable time and expertise to improve and clarify this manuscript, which is much appreciated.

\section{Authors' contributions}

CRediT author statement. DL helped in software, data curation, validation, modelling, and conceptualization. Jl reviewed and edited the manuscript. Both were involved in investigation, methodology, visualization, original draft preparation. All authors have approved the manuscript for submission. All authors read and approved the final manuscript.

\section{Funding}

Agroscope.

\section{Availability of data and materials}

The datasets used and/or analysed during the current study are available from the corresponding author on reasonable request.

\section{Declarations}

\section{Competing interests}

No potential competing interests.

Received: 11 December 2020 Revised: 16 December 2021 Accepted: 17 December 2021

Published online: 02 February 2022

\section{References}

Abbott P, Paarlberg P (1986) Modeling the impact of the 1980 grain embargo. In: Embargoes, surplus, disposal, and U.S. agriculture: a summary. United States Department of Agriculture. https://naldc.nal.usda.gov/download/CAT87 872440/PDF. Accessed 14 Dec 2021

Amikuzuno J (2011) Spatial price transmission analysis in Ghanaian agricultural markets: does the data frequency improve our estimation? J Econ Financ Sci 4(2):301-316. https://doi.org/10.4102/jef.v4i2.322

Anderson K (1983) Growth of agricultural protection in East Asia. Food Policy 8(4):327-336. https://doi.org/10.1016/03069192(83)90053-2

Arnade C, Osborne S (2004) Measurement and testing for equality of foreign price and Consumer Price Index transmission in Russia. Can J Agric Econ 52:107-125. https://doi.org/10.1111/j.1744-7976.2004.tb00097.x 
Åslund A (1998) Russia's financial crisis: causes and possible remedies. Post-Sov Geogr Econ 39:309-328. https://doi.org/ 10.1080/10889388.1998.10641079

Banse M, Duric I, Götz L, Laquai V (2019) From the Russian food import ban to free trade from Lisbon to Vladivostok - Will farmers benefit? J Int Stud 12:20-31. https://doi.org/10.14254/2071-8330.2019/12-4/2

Berendeeva E, Ratnikova T (2018) Modeling the food embargo impact on the Russian households' consumption. HSE Econ J 22:9-39. https://doi.org/10.17323/1813-8691-2018-22-1-9-39 (in Russian)

Borodin K (2016) The impact of the embargo and sanctions on the agri-food markets in Russia: analysis of consequences. Vopr Ekon 4:124-143. https://doi.org/10.32609/0042-8736-2016-4-124-143 (in Russian)

Boulanger P, Dudu H, Ferrari E, Philippidis G (2016) Russian roulette at the trade table: a specific factors CGE analysis of an agri-food import ban. Am J Agric Econ 67:272-291. https://doi.org/10.1111/1477-9552.12156

Brooks K, Gardner B (2004) Russian agriculture in the transition to a market economy. Econ Dev Cult Change 52:571-586. https://doi.org/10.1086/386534

Burakov D (2016) Oil prices, exchange rate and prices for agricultural commodities: empirical evidence from Russia. AGRIS on-Line Pap Econ 8(2):33-47. https://doi.org/10.7160/aol.2016.080203

Cheptea A, Gaigné C (2020) Russian food embargo and the lost trade. Eur Rev Agric Econ 47:684-718. https://doi.org/10. 1093/erae/jbz032

Cummings RG, Ganderton PT, McGuckin T (1994) Substitution effects in CVM values. Am J Agric Econ 76:205-214. https://doi.org/10.2307/1243622

Dickey DA, Fuller WA (1979) Distribution of the estimators for autoregressive time series with a unit root. J Am Stat Assoc 74(366):427-431. https://doi.org/10.2307/2286348

Dillen K (2015) The Russian ban on EU agricultural imports: a bilateral extension of AGLINK-COSIMO. Paper presented at the 29th conference of the International Association of Agricultural Economists, Milan, Italy, 9-14 August 2015. https://doi.org/10.22004/ag.econ.211574

Dreger C, Kholodilin KA, Ulbricht D, Fidrmuc J (2016) Between the hammer and the anvil: the impact of economic sanctions and oil prices on Russia's ruble. J Comp Econ 44:295-308. https://doi.org/10.1016/j.jce.2015.12.010

Engle RF, Granger CWJ (1987) Co-integration and error correction: representation, estimation and testing. Econometrica 55:251-276. https://doi.org/10.2307/1913236

Esposti R, Listorti G (2013) Agricultural price transmission across space and commodities during price bubbles. Agric Econ 44:125-139. https://doi.org/10.1111/j.1574-0862.2012.00636.x

European Commission (2014) EU asks WTO to rule on Russian pork import restrictions. 30 June 2014. https://ec.europa. eu/commission/presscorner/detail/en/IP_14_755. Accessed 14 Dec 2021

Fedoseeva S, Herrmann R (2019) The price of sanctions: an empirical analysis of German export losses due to the Russian agricultural ban. Can J Agric Econ 67:417-431. https://doi.org/10.1111/cjag.12194

FedStat (2020) The portal of Russian federal statistics. https://www.fedstat.ru. Accessed 14 Dec 2021. (In Russian)

Ghasemi A, ZahediasI S (2012) Normality tests for statistical analysis: a guide for non-statisticians. Int J Endocrinol Metab 10:486-489. https://doi.org/10.5812/ijem.3505

Götz L, Jaghdani T (2017) Russia's agricultural import substitution policy: price volatility effects on the pork supply chain. Paper presented at the 57th annual conference of the German Association of Agricultural Economists (GeWiSoLa), Weihenstephan, Germany, 13-15 September 2017. https://doi.org/10.22004/ag.econ.262003

Gohin A (2017) On the economic costs of the Russian embargos on food products. Rev Econ Polit 127:71-91 (in French)

Granger C (1969) Investigating causal relations by econometric models and cross-spectral methods. Econometrica 37(3):424-438. https://doi.org/10.2307/1912791

International Trade Centre (2020) Trade statistics. https://www.trademap.org

Isaac AG, Rapach DE (1997) Monetary shocks and relative farm prices: a re-examination. Am J Agric Econ 79:1332-1339. https://doi.org/10.2307/1244289

Johansen S (1991) Estimation and hypothesis testing of cointegration vectors in Gaussian vector autoregressive models. Econometrica 59(6):1551-1580. https://doi.org/10.2307/2938278

Kadochnikov PA, Knobel AY, Chentsov AM (2019) Assessment of import substitution due to the trade embargo in Russia, 2014-2016. Ekonomicheskaya Politika 14:8-33. https://doi.org/10.18288/1994-5124-2019-1-8-33 (in Russian)

Kiselev S, Strokov A, Zhorova M, Belugin A (2015) Russia's agro-industrial complex under conditions of sanctions and the need to ensure food security. AIC Econ Manag 2:12-19 (in Russian)

Kiselev S, Strokov A, Zhorova M, Belugin A (2016) The impact of food trade restrictions on the Russian agriculture. Agrar Perspect XXV:147-154

Koester U (1991) The experience with liberalization policies: the case of the agricultural sector. Eur Econ Rev 35(2-3):562-570. https://doi.org/10.1016/0014-2921(91)90158-F

Kutlina-Dimitrova Z (2017) The economic impact of the Russian import ban: a CGE analysis. Int Econ Econ 14:537552. https://doi.org/10.1007/s10368-017-0376-4

Kuzminov I, Gokhberg L, Thurner T, Khabirova E (2018) The current state of the Russian agricultural sector. EuroChoices 17:52-57. https://doi.org/10.1111/1746-692X.12184

Liefert WM, Liefert O, Seeley R, Lee T (2019) The effect of Russia's economic crisis and import ban on its agricultural and food sector. J Eurasian Stud 10:119-135. https://doi.org/10.1177/1879366519840185

Loy JP, Weaver RD (1998) Inflation and relative price volatility in Russian food markets. Eur Rev Agric Econ 25:373-394. https://doi.org/10.1093/erae/25.3.373

NSP (2020) National Union of Poultry Producers of Russia. https://poultryunion.org. Accessed 14 Dec 2021

NSSRF (2020) National Union of Pork Producers of Russia. http://www.nssrf.ru. Accessed 14 Dec 2021

Osborne SR, Liefert WM (2004) Price and exchange rate transmission in Russian meat markets. Comp Econ Stud 46:221-244. https://doi.org/10.1057/palgrave.ces.8100048

Pesaran MH (2015) Time series and panel data econometrics. Oxford University Press, Oxford. https://doi.org/10.1093/ acprof:oso/9780198736912.001.0001

Pfaff B (2008a) VAR, SVAR and SVEC models: implementation within R package vars. J Stat Softw 27(4):32. https://doi. org/10.18637/jss.v027.i04 
Pfaff B (2008b) Analysis of integrated and cointegrated time series with R, 2nd edn. Springer, New York (ISBN 0-38727960-1 (Package 'urca'))

Ponomareva E, Magomedov R (2017) Impact of product sanctions on Russian prices in 2014-2016. Rus Econ Dev 24:26-34 (in Russian)

Prikhodko D, Davleyev A (2014) Russian Federation: Meat sector review. Russia, Food and Agriculture Organization of the United Nations

Rosstat (2020) Official Russian statistics. www.gks.ru. Accessed 14 Dec 2021

Rutland P (2014) The impact of sanctions on Russia. Russ Anal Dig 157:17

Schierhorn F, Meyfroidt P, Kastner T, Kuemmerle T, Prishchepov AV, Müller D (2016) The dynamics of beef trade between Brazil and Russia and their environmental implications. Glob Food Sec 11:84-92. https://doi.org/10. 1016/j.gfs.2016.08.001

Semenova N, Sundikova I (2015) The Russian food import ban: which party suffers more? Financ Anal Sci Exp 40:37-45 (in Russian)

Serova EV (2007) Agro-holdings: vertical integration in agri-food supply chains in Russia. In: Swinnen JFM (ed) Global supply chains, standards and the poor: how the globalization of food systems and standards affects rural development and poverty. Wallingford, Oxforshire, pp 188-205

Shagaida N (2019) Institutional restructuring of agriculture is complete: what is next? Rus Peasant Stud 4:173-178. https://doi.org/10.22394/2500-1809-2019-4-1-171-175 (in Russian)

Shagaida N, Uzun V (2015a) Agriculture and food: does import substitution take place? Rus Econ Dev 11:51-54. https:// doi.org/10.2139/ssrn.2701386 (in Russian)

Shagaida N, Uzun V (2015b) Food security: problems of assessing. Vopr Ekon 5:63-78. https://doi.org/10.32609/00428736-2015-5-63-78 (in Russian)

Shagaida N, Uzun V (2016) Food embargo and choice of priorities. Vopr Ekon 7:93-105. https://doi.org/10.32609/00428736-2016-7-93-105 (in Russian)

Shagaida N, Uzun V, Gataulina E, Shishkina E, Zhorova M (2016) Elaboration of approaches for depicting the priorities of Russian agriculture development. SSRN J. https://doi.org/10.2139/ssrn.3071505 (in Russian)

Smirnov SN (2016) Economic sanctions, food embargo and market conditions in Russia. Econ Soc Probl Rus 2:55-78 (in Russian)

Svanidze M, Götz L (2019a) Spatial market efficiency of grain markets in Russia: implications of high trade costs for export potential. Glob Food Sec 21:60-68. https://doi.org/10.1016/j.gfs.2019.07.004

Svanidze M, Götz L (2019b) Determinants of spatial market efficiency of grain markets in Russia. Food Policy 89:101769. https://doi.org/10.1016/j.foodpol.2019.101769

Trapletti A, Hornik K (2019) tseries: Time series analysis and computational finance. R package version 0.10-47. https:// cran.r-project.org/web/packages/tseries/index.html. Accessed 14 Dec 2021

Uzun V, Loginova D (2016) Russian food embargo: minor losses in western countries. Rus Econ Dev 9:32-37. https://doi. org/10.2139/ssrn.2842146 (in Russian)

Uzun V, Loginova D (2017) Will Russia become food net exporter? Monit Rus Econ Dev 1:18-20. https://doi.org/10.2139/ ssrn.2944578 (in Russian)

Uzun V, Fomin A, Loginova D (2018) Position of Russia on the world agro-food map. Int Agric J 1(361):68-76. https://doi. org/10.24411/2587-6740-2018-11016 (in Russian)

Volchkova N, Kuznetsova P (2019) How much do counter-sanctions cost: well-being analysis. J New Econ Assoc 43:173-183. https://doi.org/10.31737/2221-2264-2019-43-3-9 (in Russian)

Wang Y, Wang K, Chang C-P (2019) The impacts of economic sanctions on exchange rate volatility. Econ Model 82:58-65. https://doi.org/10.1016/.econmod.2019.07.004

Wegren S (2014) Russia's food embargo. Russ Anal Dig 157:13-16

Yugay S, Götz L, Svanidze M (2020). Exchange rate pass-through and wheat prices in Russia. Paper presented at the 60th annual conference of the German Association of Agricultural Economists, Halle, Germany, 23-25 September 2020. https://doi.org/10.22004/ag.econ.305595

\section{Publisher's Note}

Springer Nature remains neutral with regard to jurisdictional claims in published maps and institutional affiliations. 